\title{
Stereotypes and Terror Management: Evidence That Mortality Salience Enhances Stereotypic Thinking and Preferences
}

\author{
Jeff Schimel, Linda Simon, and Jeff Greenberg \\ University of Arizona
}

Sheldon Solomon
Skidmore College

\author{
Tom Pyszczynski \\ University of Colorado at Colorado Springs \\ Jeannette Waxmonsky \\ University of Alabama
}

\author{
Jamie Arndt \\ University of Arizona
}

\begin{abstract}
If stereotypes function to protect people against death-related concerns, then mortality salience should increase stereotypic thinking and preferences for stereotype-confirming individuals. Study 1 demonstrated that mortality salience increased stereotyping of Germans. In Study 2, it increased participants' tendency to generate more explanations for stereotype-inconsistent than stereotype-consistent gender role behavior. In Study 3, mortality salience increased participants' liking for a stereotype-consistent African American and decreased their liking for a stereotype-inconsistent African American; control participants exhibited the opposite preference. Study 4 replicated this pattern with evaluations of stereotypeconfirming or stereotype-disconfirming men and women. Study 5 showed that, among participants high in need for closure, mortality salience led to decreased liking for a stereotype-inconsistent gay man.
\end{abstract}

Stereotypes, overgeneralized beliefs about members of a group, are commonly considered to be important contributors to prejudice, discrimination, and intergroup conflict. Not surprisingly, then, these cognitive constructs have been fruitfully studied from a variety of theoretical perspectives (e.g., Jussim, Coleman, \& Lerch, 1987; Macrae, Stangor, \& Hewstone, 1996). Over the last five decades, a variety of theorists and researchers have focused on the functions that stereotypes serve for both individuals and cultures (e.g., Allport, 1954; Fishman, 1956; Harding, Proshansky, Kutner, \& Chein, 1969; Snyder \& Miene, 1994; Stangor \& Schaller, 1996); this was the perspective taken in the present research.

One oft-discussed set of functions concerns justifying prejudice and discrimination (e.g., Allport, 1954; Myrdal, 1944; Ryan, 1971). Another related set of functions focuses on helping indi-

Jeff Schimel, Linda Simon, Jeff Greenberg, and Jamie Arndt, Department of Psychology, University of Arizona; Tom Pyszczynski, Department of Psychology, University of Colorado at Colorado Springs; Sheldon Solomon, Department of Psychology, Skidmore College; Jeannette Waxmonsky, Department of Psychology, University of Alabama.

Jamie Arndt is now at the Department of Psychology, University of Missouri-Columbia.

This research was supported in part by National Science Foundation Grants SBR-9212798, SBR-9312546, and SBR-9601474. The first two authors' contributions were equivalent. We thank James Turner for his help as a confederate in Study 3 and Iren Hammerbekk for her work as an experimenter in Study 4.

Correspondence concerning this article should be addressed to Jeff Schimel, Department of Psychology, University of Arizona, Tucson, Arizona 85721 . Electronic mail may be sent to jschimel@u.arizona.edu. viduals and groups enhance their sense of worth through downward social comparison (see, e.g., Allport, 1954; Tajfel \& Turner, 1979; Wills, 1981). Given that stereotypic depictions of out-group members are typically quite negative, it is easy to see how such beliefs could serve these purposes. However, stereotypes also often include acknowledgment of some positive characteristics of out-groups (e.g., African Americans are gifted athletes and musicians, Jews are good doctors and lawyers, and gay men are artistic and well dressed; e.g., Devine \& Baker, 1991). This suggests that stereotypes may serve other functions as well. Perhaps the most basic of these functions is to provide clear, simple, and potentially useful information about out-groups (e.g., Allport, 1954; Oakes \& Turner, 1990). Consistent with this view, stereotypes accentuate differences between groups (e.g., Stangor \& Ford, 1992) and imply that one can predict a great deal about an individual on the basis of her or his group membership (e.g., Diehl \& Jonas, 1991).

Although this informational function helps explain why stereotypes arise in the first place, once stereotypes have emerged, they may come to serve another function: terror management. Once established, culturally prevalent stereotypes may become significant components of the worldview espoused by that culture. Even a casual glance at television and movies in the United States attests to the centrality of these constructs. Indeed, as Devine (1989) has shown, Black American stereotypes seem to come to the minds of White Americans quite readily whenever White Americanswhether highly prejudiced or not-are exposed to cues associated with Black Americans, even if the exposure is outside of conscious awareness. Terror management theory (TMT; Greenberg, Pyszczynski, \& Solomon, 1986; Solomon, Greenberg, \& Pyszczynski, 1991) posits that an individual's cultural worldview is a culturally derived yet individualized conception of reality that provides pro- 
tection against deeply rooted fears of human mortality and vulnerability. To the extent that stereotypes are significant components of such a worldview, people would be expected to be especially committed to maintaining their stereotypes when reminded of the source of their fear. Thus, mortality salience would be expected to increase one's tendency to perceive individual members of outgroups in stereotypic ways and lead to a preference for stereotypeconsistent out-group members over stereotype-inconsistent ones. The research reported in this article was designed to test these hypotheses.

\section{Terror Management Theory and Research}

TMT posits that the juxtaposition of an instinctive desire for continued life with awareness of the inevitability of death creates the potential for paralyzing terror. Cultural conceptions of reality evolved, in part, to provide protection against this most basic of all human fears. From the perspective of TMT, this protection against death-related anxiety is provided by a dual-component cultural anxiety buffer consisting of (a) a cultural worldview, which provides a meaningful, orderly, and stable conception of reality, a set of standards through which individuals can attain a sense of personal value, and the promise of literal or symbolic immortality to those who live up to these standards of value, and (b) selfesteem, which is acquired by believing in the absolute validity of one's cultural worldview and that one is living up to its standards of value. Because of the vital role that these two psychological structures play in protecting an individual against deeply rooted anxiety, a great deal of behavior is oriented toward maintaining these structures and defending them against threats.

Over the past decade, a substantial body of research has accumulated in support of TMT's primary propositions (for a review, see Greenberg, Solomon, \& Pyszczynski, 1997). Research testing the anxiety-buffering hypothesis of self-esteem has shown that increasing self-esteem reduces self-reports of anxiety in response to graphic depictions of death, physiological arousal in response to the threat of painful electric shock, and defensive distortions to deny one's vulnerability to an early death (e.g., Greenberg et al., 1993; Greenberg, Solomon, et al., 1992). Research has also shown that both experimentally induced boosts to self-esteem and high levels of dispositional self-esteem reduce the effects of mortality salience on cultural worldview defense and eliminate the delayed increase in the accessibility of death-related thoughts that typically occurs in response to reminders of one's mortality (Harmon-Jones et al., 1997).

More than 50 separate tests of the mortality salience hypothesis, conducted in five different countries, have shown that reminders of one's mortality increase the positivity of evaluations of people and ideas that support one's cultural worldview and the negativity of evaluations of people and ideas that threaten it (e.g., Greenberg et al., 1990; Greenberg, Pyszczynski, Solomon, Simon, \& Breus, 1994; Greenberg, Simon, Pyszczynski, Solomon, \& Chatel, 1992; Ochsmann \& Mathy, 1994; Rosenblatt, Greenberg, Solomon, Pyszczynski, \& Lyon, 1989). Research has also shown that mortality salience increases the tendency to conform to the standards of one's cultural worldview (Greenberg et al., 1993), makes it harder to violate cultural norms (Greenberg, Simon, Porteus, Pyszczynski, \& Solomon, 1995), increases optimal distinctiveness strivings (Simon, Greenberg, Arndt, et al., 1997), and increases estimates of social consensus for culturally relevant attitudes among those holding minority positions (Pyszczynski et al., 1996). Furthermore, these effects appear to be specific to the problem of death. A wide variety of parallel inductions in which participants are induced to think about other aversive or anxiety-provoking events do not produce similar effects (e.g., Greenberg et al., 1994; Greenberg, Simon, Harmon-Jones, et al., 1995).

\section{A Terror Management Perspective on Prejudice and Stereotyping}

The idea that stereotypes may serve a self-protective or selfenhancing function is, of course, not new (e.g., Allport, 1954). Consistent with this notion, Tajfel and Turner (1979) proposed that people are motivated to maintain a positive self-image by enhancing the value of the group to which they belong (i.e., their social identity). Some of the earliest evidence for this idea comes from research showing that when people are divided into groups in the minimal group paradigm (e.g., Billing \& Tajfel, 1973), individuals come to see the group to which they belong more favorably (e.g., Oakes \& Turner, 1980). One implication of this early theorizing and research is that, to the extent that stereotypes about other groups bolster one's social identity, such beliefs may satisfy a self-esteem motive. By viewing out-group members as inferior to oneself and other in-group members, one is able to increase one's sense of personal and group value in a relative sense; this, of course, is the process of downward comparison, viewed by many social psychological theories as playing an important role in prejudice (e.g., Allport, 1954; Festinger, 1954; Tajfel \& Turner, 1979; Wills, 1981). Recent research by Fein and Spencer (1997) directly assessed the function of stereotypes for self-esteem maintenance. In this research, Fein and Spencer (1997) found that when selfesteem was threatened, individuals responded more negatively to stereotyped out-group members and that when they were given a chance to self-affirm after such threats, they were less likely to treat out-group members according to negative stereotypes. It has also been suggested that stereotypes function to preserve the social system or "status quo." In support of this notion, several studies have shown that gender stereotypes bring about a division of labor and help people rationalize the existence of a division of labor between men and women (see Jost \& Banaji, 1994, for a review). Together, this evidence suggests that when people are concerned with enhancing their personal value, bolstering their group identity, or preserving the social system, they may rely more heavily on stereotypes that help serve these functions. According to TMT, stereotypes may also serve another, even more basic psychological function.

From the perspective of TMT, hostility toward those who are different results not only from the implications that such people have for the individual's own sense of personal value but also from the implications such people have for faith in the individual's cultural worldview. TMT suggests that, because cultural worldviews are fragile symbolic constructions maintained through a process of social consensus, the mere existence of differences between oneself and others calls into question the absolute validity and correctness of one's own beliefs, values, and lifestyle. Because such threats challenge an individual's faith in his or her worldview, he or she is likely to respond to those with divergent worldviews with disdain and hostility. 
Consistent with this notion, a large body of evidence has demonstrated that reminders of mortality increase negative evaluations of and behavior toward out-group members and dissimilar others and increase positive evaluations of and behavior toward in-group members and similar others. For example, Greenberg et al. (1990) demonstrated that mortality salience led Christian participants to evaluate a fellow Christian more favorably and a Jew more negatively. Kunzendorf, Hersey, Wilson, and Ethier (1992) demonstrated that mortality salience led American college students to increase their agreement with the statement that "the holocaust in Nazi Germany was God's punishment for the Jews." Ochsmann and Mathy (1994) have shown that mortality salience led German college students to express more negative attitudes toward foreigners and to sit closer to a fellow German and further away from a person who appeared to be of Turkish descent. Harmon-Jones, Greenberg, Solomon, and Simon (1996) have shown that mortality salience leads to increased in-group bias in the minimal group paradigm, as long as group membership is assigned on a meaningful rather than random basis. Taken together, these studies suggest that hostility and disdain toward those who are different function, at least in part, to provide protection against death-related fear. By derogating those who are different, the individual deflects any threat posed by this deviance and thus reasserts the correctness and validity of his or her own anxiety-buffering cultural worldview.

Despite this general tendency to reject out-group members, minority groups are clearly a part of both prejudiced and nonprejudiced White Americans' social world (e.g., Allport, 1954; Devine, 1989), and stereotypic beliefs about out-group members are likely to be a significant component of their conception of social reality (e.g., Stangor \& Schaller, 1996). According to TMT, cultural worldviews assuage anxiety by imbuing the world with meaning, order, and predictability; by providing standards through which individuals can achieve personal value; and by promising some form of death transcendence to those who live up to these standards. To the extent that cultural stereotypes of out-group members contribute to these meaningful, orderly, and stable conceptions of the social world, they too should function to provide protection against deeply rooted existential fear. Interestingly, this is similar in some ways to the cognitive view that prejudice results primarily from cognitive laziness or the over-application of cognitive simplification strategies that are otherwise adaptive. Indeed, a good deal of research suggests that stereotypic beliefs may result from a failure to engage in covariance reasoning (Schaller, 1992, 1994; Schaller \& O'Brien, 1992), the tendency to perceive illusory correlations (Hamilton \& Rose, 1980), and the simplistic perception of group means and variances (Ford \& Stangor, 1992). TMT suggests, however, that this tendency to maintain one's preexisting social conceptions results not only from simple cognitive biases or heuristics but also from the need for the protection from deeply rooted anxiety that such orderly conceptions of social reality provide. From the perspective of TMT, stereotypes are part of the orderly and stable cultural reality on which individuals rely to feel secure.

\section{Study 1}

To the extent that stereotypes are part of the cultural worldview that provide protection from mortality concerns, reminders of one's mortality might be expected to increase the use of stereotypes. Consistent with this reasoning, Greenberg et al. (1990, Study 1) have shown that mortality salience led Christian participants to attribute more negative stereotypic traits (e.g., cheap) to a Jewish target person. Unfortunately, because only negative stereotypic trait ascriptions were assessed in that study, it is not entirely clear that these findings reflect a genuine tendency to maintain the stereotype as opposed to a tendency to simply derogate the minority group member in a culturally legitimized way. If the maintenance of consistent group stereotypes serves a terror management function, then one would expect mortality salience to increase the attribution of stereotypic traits to individual out-group members regardless of the valence of the traits or group in question. Study 1 tested this hypothesis by investigating the effects of mortality salience on stereotype ascriptions to Germans, a group toward which pilot studies suggested that our population of American college students have relatively favorable feelings (in fact, Germans received the most favorable ratings of the six national groups evaluated in our pilot study and were even given nonsignificantly higher ratings than Americans).

As a means of testing this hypothesis, American college students were induced to write about either their own mortality or a neutral topic (watching television). Then, by means of a procedure similar to those developed by Brigham (1971) and Eagly and Mladinic (1989), participants were asked to estimate the percentage of Germans who possess a variety of stereotypic personality traits. An additional purpose of Study 1 was to determine whether the presence of a German person would affect the use of stereotypes in response to mortality salience. Thus, experimental sessions were run by either a German or American female experimenter. Because the nationality of the experimenter had no significant effects on stereotyping, this hypothesis is not discussed further.

\section{Method}

Participants. Twenty-eight female and 13 male undergraduates at the University of Colorado at Colorado Springs who had not taken psychology classes were solicited in the school cafeteria and paid $\$ 5$ for their participation in a $30-\mathrm{min}$ experimental session.

Procedure. Participants completed the experiment in groups of 2 to 6 and were randomly assigned to conditions in a 2 (mortality salience: death vs. television) $\times 2$ (nationality of experimenter: American vs. German) factorial design. Whereas each session was conducted by either a German or American female experimenter, roughly equal numbers of mortality salient and control participants took part in each session. On arriving for the experiment, participants were greeted by either an American or German experimenter (unaware of the mortality salience conditions) who introduced herself as "Jenny" or "Heidi Schmidt" and spoke in either an American or German accent. As in previous mortality salience studies (e.g., Greenberg, Simon, et al., 1992; Simon, Greenberg, Harmon-Jones, et al., 1997), participants were told that they were taking part in two short studies, the first for the experimenter's advisor and the second for the experimenter's master's thesis. The first study was described as an investigation of "how different objective and subjective personality measures are correlated." Participants were then given the first packet of questionnaires and instructed to work through them in order and to "just give your natural, gut level responses to the questions." The mortality salience manipulation was embedded in this packet.

After completion of this "first study," the packets were collected, and participants were given a second set of questionnaires. This set of forms was described as being a part of a "second study" that concerned how individuals perceived people from various countries. Participants were then 
instructed to estimate the percentage of persons from each of the three countries listed on their forms (Germany, United States, and Italy) who had each of the personality traits listed. Ratings of Germans and Americans were solicited to construct the dependent measure of stereotyping; ratings of Italians were solicited to disguise the focus of the study on German stereotypes. On completion of this measure, participants were debriefed, paid $\$ 5$, and thanked for taking part.

Materials. The first questionnaire packet consisted of some filler personality measures to maintain consistency with the cover story (e.g., the Social Desirability Inventory [Crowne \& Marlowe, 1960]), the mortality salience manipulation, and the Positive and Negative Affect Schedules (PANAS-X; Watson, Clark, \& Tellegen, 1988). The second questionnaire packet consisted of the stereotyping measure, a demographic questionnaire, and two debriefing questions that probed for suspicion (no suspicion was detected by either these questions or oral debriefing).

The mortality salience manipulation consisted of two open-ended questions about either participants' own death or watching television that have been used in previous TMT studies (e.g., Greenberg et al., 1990, 1993; Rosenblatt et al., 1989). ${ }^{1}$ Participants were instructed as follows: "Briefly describe the thoughts and feelings that the thought of your own death [watching television] arouses in you" and "Please describe in as much detail possible what you think will happen as you die [watch television] and once you are physically dead [or as you watch television]."

The stereotype measure consisted of a list of 51 trait adjectives. Participants were asked to estimate what percentages of Germans, Americans, and Italians have each trait. Each of the 51 items was previously rated by our student population as characteristic of Germans, Americans, and Italians. Seventeen items showed a significant difference between ratings of the typical German and American in pilot testing. Of these 17 items, 5 also showed a significant difference between Italians and Americans. After elimination of these 5 overlapping items, 12 traits unique to Germans (unemotional, disciplined, proud, hardworking, loyal, regimented, organized, very neat, stubborn, orderly, rigid, and stern) were used in our composite measure of stereotyping.

\section{Results and Discussion}

Stereotyping. Our data analysis strategy was patterned after McCauley and Stitt's (1978; McCauley, Stitt, \& Segal, 1980) diagnostic ratio approach to measuring stereotypes. A diagnostic ratio is computed by dividing participants' percentage ratings of a particular group on a series of traits by their percentage ratings of a comparison group (in this case, the in-group) on the traits. According to McCauley and Stitt (1978; McCauley et al., 1980), a diagnostic ratio is more accurate than raw percentage ratings because diagnostic ratios take into account the relative stereotyping of the comparison group on a particular set of traits. ${ }^{2}$ On the basis of these recommendations, separate composite measures of stereotyping were constructed by summing participants' ratings of Germans and Americans on the stereotypic traits. We then computed a diagnostic ratio of stereotyping for Germans by dividing the German composite by the American composite. A 2 (mortality salience: death vs. television) $\times 2$ (nationality of experimenter: German vs. American) analysis of variance (ANOVA) performed on this composite measure revealed a significant main effect of mortality salience, $F(1,37)=5.42, p<.05 .{ }^{3}$ Consistent with our predictions, mortality salient participants exhibited higher levels of stereotyping than television control participants $(M \mathrm{~s}=1.41$ and 1.20, respectively). No significant effect of experimenter nationality or Mortality Salience $\times$ Experimenter interaction was found (both $p s>.50$ ). Mortality salience thus led to higher levels of stereotyping regardless of the nationality of the experimenter.

To the extent that Italians do not possess traits stereotypic of Germans, mortality salience should not increase participants' ratings of Italians on the German stereotypic traits. To test this idea, we computed the same diagnostic ratio measure for Italians (by summing the ratings for Italians on the German traits and dividing by the ratings for Americans on the same traits). We submitted the diagnostic ratio measures of Germans and Italians to a 2 (mortality salience: death vs. television) $\times 2$ (target group: Italian vs. German) ANOVA with target group as a repeated measures variable. This analysis revealed a significant main effect of target group, $F(1,39)=43.42, p<.001$, indicating that Germans were viewed as having more of the German traits than Italians. This main effect was qualified by a significant Mortality Salience $\times$ Target Group interaction, $F(1,39)=4.50, p<.05$. Pairwise comparisons showed that, for ratings of Germans, the mortality salience condition led to increased stereotyping over the control condition, $t(39)=3.35, p<.01$. However, for ratings of Italians, there was no significant increase in stereotyping over television control participants $(p>.50)$. Thus, as we expected, mortality salient participants did not increase their ascriptions of the German traits to Italians. The means and standard deviations for this analysis are presented in Table 1.

In designing this study, we focused specifically on the German stereotype and so included traits we thought might fit that stereotype. However, we did find in our pretest data that a few of the traits were viewed as stereotypic of Italians. If mortality salience leads to an increase in stereotyping of Germans, we suspected that mortality salience might also lead to an increase in stereotyping of Italians. To investigate this possibility, we created an Italian stereotype composite that consisted of the

\footnotetext{
${ }^{1}$ In three of the five studies reported in this article, the relatively neutral "thoughts of television" control group was used. A variety of recent mortality salience studies have contrasted thoughts of death with thoughts of other aversive events such as poor exam performance, giving a speech in front of a large audience, the breakup of an important romantic relationship; and being paralyzed. None of these aversive control conditions has produced effects parallel to mortality salience. On the basis of these findings, along with the findings of Studies 2 and 4 of the present article (contrasting thoughts of death with thoughts of dental pain and social exclusion, respectively), we believe it is safe to conclude that our findings are specific to concerns about death.

${ }^{2}$ We also conducted separate $t$ tests to determine whether mortality salience would increase the raw percentage ratings of Germans, Italians, or Americans on the 12 stereotypic German traits over control participants. None of the comparisons was significant. However, the pattern of means showed that the mortality salience condition, relative to the control condition, increased the raw percentage ratings for Germans $(M \mathrm{~s}=849.21$ and 788.59), decreased ratings for Americans ( $M \mathrm{~s}=621.94$ and 664.09), and slightly decreased ratings for Italians ( $M \mathrm{~s}=647.52$ and 673.90$)$.

${ }^{3}$ Preliminary analyses included gender of participant and order of ratings of the targets. There were no effects for either of these variables, and so they were not included in the final analyses. We also included gender of participant in initial analyses in Studies 3 and 5 (only female participants took part in Study 2 and Study 4) and order of appearance of targets in Study 3. There were no effects of these variables in either study, so we did not include them in the final analyses.
} 
Table 1

Cell Means for the Two-Way Mortality Salience $\times$ Target Group (German vs. Italian) Interaction in Study 1

\begin{tabular}{|c|c|c|c|c|c|c|c|c|}
\hline \multirow[b]{4}{*}{ Trait composite } & \multicolumn{8}{|c|}{ Target group } \\
\hline & \multicolumn{4}{|c|}{ Germans } & \multicolumn{4}{|c|}{ Italians } \\
\hline & \multicolumn{2}{|c|}{ Mortality salient } & \multicolumn{2}{|c|}{ TV } & \multicolumn{2}{|c|}{ Mortality salient } & \multicolumn{2}{|c|}{ TV } \\
\hline & $M$ & $S D$ & $M$ & $S D$ & $M$ & $S D$ & $M$ & $S D$ \\
\hline German traits & $1.41_{\mathrm{a}}$ & 0.29 & $1.20_{\mathrm{b}}$ & 0.26 & $1.05_{c}$ & 0.26 & $1.02_{\mathrm{c}}$ & 0.18 \\
\hline Italian traits & $1.05_{\mathrm{c}}^{\mathrm{a}}$ & 0.75 & $0.89_{c}^{\circ}$ & 0.32 & $1.67 \mathrm{a}$ & 0.91 & $1.25_{\mathrm{b}}$ & 0.40 \\
\hline Neutral traits & $1.05_{\mathrm{a}}$ & 0.19 & $1.01_{a}$ & 0.10 & $1.02_{\mathrm{a}}$ & 0.12 & $1.02_{\mathrm{a}}$ & 0.14 \\
\hline
\end{tabular}

Note. Means within rows that do not share a common subscript differ at $p<.05$ (two-tailed) within conditions. A higher number indicates increased ascriptions of the stereotypic traits.

three traits that our pretest data showed were unique to Italians (passionate, sensual, and artistic) and then summed these traits for Italians and Americans separately. ${ }^{4}$ As in our previous analyses, we computed diagnostic ratios by dividing ratings of Italians and Germans by ratings of Americans on these traits. We submitted these measures to a 2 (mortality salience: death vs. television) $\times 2$ (target group: Italian vs. German) ANOVA using target group as a repeated measures variable. This analysis revealed a main effect of target group, $F(1,39)=34.14, p<.001$, indicating that Italians were rated as having more of the Italian traits than Germans. There was only a hint of a Mortality Salience $\times$ Target Group interaction, $F(1,39)=2.32, p<.13$. Although the interaction was not significant, the pattern of means mirrored what we found for the German stereotypic traits (see Table 1 for means).

Supplemental analyses. Additional analyses were conducted to determine whether the effect of mortality salience on stereotyping of Germans generalized to both positive and negative stereotypic traits and was indeed specific to traits that are uniquely stereotypic of Germans. With regard to the first issue, recall that a terror management perspective on stereotyping predicts that mortality salience should increase stereotyping of Germans regardless of the valence of the traits. Therefore, we tested to see whether mortality salience increased stereotyping of Germans on both positive and negative stereotypic traits. Among the 12 stereotypic traits, means were computed for the positive traits (disciplined, loyal, organized, hardworking, proud, very neat, and orderly) and the negative traits (stubborn, unemotional, regimented, rigid, and stern) for Germans and Americans. Diagnostic ratios were then computed by dividing the mean ratings for Germans on the positive traits by the mean ratings for Americans on the positive traits. The same measure was computed for the negative traits. These measures were then submitted to a 2 (mortality salience: death vs. television) $\times 2$ (trait valence: positive vs. negative) ANOVA with the positive and negative traits as a repeated measures variable. This analysis revealed only the expected main effect of mortality salience, $F(1,39)=4.66, p<.05$, indicating that the mortality salience condition increased stereotyping of Germans on both positive and negative traits relative to the control condition ( $M \mathrm{~s}=1.44$ and 1.23, respectively). When looked at separately, the means for mortality salience and control for the positive traits were 1.48 and 1.24 , respectively, and the means for the negative traits were 1.40 and 1.20 .

To examine whether the effect of mortality salience on stereotyping of Germans was indeed unique to the stereotypic traits, we also tested to see whether mortality salience would increase participants' ratings of Germans on traits that are not stereotypic of Germans. Therefore, we summed 10 traits for which our pretest data showed no difference between Germans and Americans and no difference between Italians and Americans (e.g., intelligent, friendly, pushy, opinionated, and temperate) and computed diagnostic ratios for Germans and Italians on these traits. A 2 (mortality salience: death vs. television) $\times 2$ (target group: German vs. Italian) ANOVA with target group as a repeated measures variable was performed on the nonstereotypic traits and revealed no main effects or interactions (all $p s>.25$; see Table 1 for means), indicating that mortality salience did not increase trait ascriptions to Germans or Italians on the nonstereotypic traits.

Affect. We performed 2 (mortality salience: death vs. television) $\times 2$ (nationality of experimenter: German vs. American) ANOVAs on the various subscales of the PANAS-X. These analyses revealed significant main effects of mortality salience on positive affect, $F(1,37)=7.46, p<.05$; happiness, $F(1$, $37)=5.02, p<.05$; and self-assuredness, $F(1,37)=6.94, p<$ .05 . Mortality salient participants rated themselves as experiencing more positive affect $(M=3.25$ vs. 2.61$)$, as happier $(M=3.10$ vs. 2.42 ), and as more self-assured ( $M=3.07$ vs. 2.44 ) than control participants. This increase in self-reported positive affect, happiness, and self-assuredness replicates previous findings of an apparent increase in reports of positive emotions after mortality salience and may reflect a defensive attempt to deny one's concerns about death (e.g., Arndt, Greenberg, Simon, Pyszczynski, \& Solomon, 1998).

The results of Study 1 support the hypothesis that mortality

\footnotetext{
${ }^{4}$ Our pretest data originally showed that Italians were rated higher than Americans on six traits (passionate, sensual, artistic, happy, generous, and outgoing). We eliminated the last three traits from our measure of stereotyping of Italians because only the first three were originally intended to be stereotypic of Italians.
} 
salience increases the tendency to view out-group members in a stereotypic way. Participants who were reminded of their own mortality exhibited higher levels of stereotyping of Germans than controls. Whereas previous research has shown that mortality salience increases Christian participants' ascription of negative stereotypes to Jews, a group that was also generally evaluated in a more negative manner in response to mortality salience, the present study shows that mortality salience increases the ascription of stereotypic traits to Germans, a group not particularly disliked by our population of American college students. In contrast, the results for the Italian stereotype were weak. However, because our original intention was only to measure stereotypes of Germans, the measure of stereotyping of Italians was ad hoc and consisted of only three items. Thus, the weak findings for Italians may reflect the inadequacy of the ad hoc Italian stereotype composite.

These findings considerably extend the TMT analysis of prejudice by showing that mortality salience not only increases disliking for out-groups but also increases ascriptions of stereotypic traits to out-group members. Whereas a negative evaluation of those who are different presumably defuses the threat posed to one's worldview, attributing stereotypic traits to out-group members presumably functions to verify one's view of social reality through the perception of individual members of various social categories as sharing the traits ascribed to them by one's cultural stereotypes. The fact that mortality salience increased stereotyping of Germans, a group toward which pilot studies suggested that our participant population had neutral to positive attitudes, suggests that the terror management function of stereotyping does not inevitably entail derogation of such groups; rather, it can involve viewing them in a narrow, simplified way that supports the individual's overall worldview.

However, it is also possible that although the students in our pilot study did not express negative attitudes toward Germans, they may have been responding in a socially desirable or politically correct way. Indeed, the current social climate discourages overt expressions of prejudice and discrimination toward members of ethnic groups (e.g., Devine, 1989; Devine \& Elliot, 1995). This social climate might serve as motivation for people to suppress any outward expression of prejudice and dislike for out-group members (e.g., Monteith, 1993). Similarly, research demonstrates that many Americans are conflicted in their attitudes about minority group members such that, on one hand, they possess feelings of aversion and dislike and, on the other hand, they have feelings of sympathy for the minority underdog (e.g., Dovidio \& Gaertner, 1998; Hass, Katz, Rizzo, Bailey, \& Eisenstadt, 1991; Katz, 1981; Katz \& Hass, 1988). If, in fact, our student population held latent negative attitudes toward Germans, then the results of Study 1 could be interpreted in terms of previous terror management research demonstrating derogation of out-group members who directly threaten one's worldview.

To assess this possibility, we conducted our primary analyses a second time using the filler social desirability questionnaire (Crowne \& Marlowe, 1960) from the first packet of Study 1 as a covariate. These analyses did not change our results, indicating that social desirability did not play a role in the trait ascriptions. Moreover, the alternative explanation that concerns with political correctness may have influenced participants' responses seems unlikely because participants' increased tendency to stereotype Germans after thinking about their mortal- ity was not qualified by the (negative or positive) valence of the stereotypic traits. That is, participants were just as likely to ascribe stereotypic traits to Germans whether the traits were positive or negative. Of course, there is also the possibility that although our student population indicated a general liking for Germans, the stereotypic traits used in our analysis may have brought to mind the "Nazi" stereotype. Thus, mortality salience may have led participants to disparage Germans by rating them higher on traits that are a part of the Nazi stereotype (orderly, neat, and regimented).

\section{Study 2}

In Study 2, we sought to rule out this alternative explanation by using a less reactive measure of stereotyping that did not require participants to ascribe traits to a target group. Toward this end, we used a measure developed by von Hippel, Sekaquaptewa, and Vargas (1997) that taps participants' stereotypic thinking independent of any latent negative attitudes they might have toward the target group (Hastie, 1984). This measure requires participants to complete sentences about different target persons who engaged in stereotype-consistent and stereotype-inconsistent behaviors. If unexpected information is especially likely to generate causal thinking (Pyszczynski \& Greenberg, 1981; Wong \& Weiner, 1981), then completing sentences with explanations for the behavior in the stem can be taken as an indirect indication that the behavior was unexpected. Thus, to the extent that more explanations are offered for stereotype-inconsistent than for stereotype-consistent behaviors, it is reasonable to infer that the perceiver had stereotype-consistent expectations. If mortality salience increases individuals' tendency to apply stereotypes, then participants who were reminded of their mortality should have a greater tendency to complete the stereotype-inconsistent sentence stems with explanations for the target's behavior.

A second purpose of Study 2 was to extend the TMT analysis of stereotyping to social classifications of individuals other than ethnicity or religion. Specifically, we were interested in whether mortality salience would lead to an increase in stereotypic thinking concerning gender roles. Indeed, most people hold at least some stereotypes about how males and females typically behave (e.g., Biernat, 1991; Six \& Eckes, 1991). If these gender stereotypes are an important part of people's cultural conception of reality, then, from the TMT perspective, mortality salience should increase their efforts to explain information that disconfirms their stereotypes about gender.

As a means of addressing these issues, participants were induced to think about either their mortality or dental pain (an aversive topic unrelated to death) and then read several sentence stems about males and females that were either consistent or inconsistent with gender stereotypes. Following von Hippel et al. (1997), participants were asked to finish each sentence stem to form a complete sentence. We measured the number of sentence completions that explained the targets' behavior and predicted that mortality salient participants would exhibit a greater tendency to explain more stereotype-inconsistent than stereotype-consistent behaviors than would control participants. 


\section{Method}

Participants. The participants were 61 female introductory psychology students at the University of Arizona who took part in the study in exchange for partial course credit. 5

Procedure. Participants completed the experiment in groups of 3 to 5 and were randomly assigned to conditions in a 2 (mortality salience: death vs. dental pain) $\times 2$ (stereotypicality of behavior: consistent vs. inconsistent) repeated measures design. When participants arrived at the laboratory, the experimenter, who was unaware of conditions, informed them that the study concerned the relationship between different personality characteristics and that they would therefore complete a packet consisting of a variety of personality questionnaires. To ensure participants' privacy and anonymity, the experimenter collected the consent forms before administering the packet of questionnaires and had them complete the materials in individual cubicles; when finished, participants put the packet of materials in a blank envelope and then placed the envelope in a box on the floor with a stack of other envelopes. After completing the packet of materials, participants were probed for suspicion, thoroughly debriefed, and thanked for their time.

Materials. The mortality salience manipulation and the attributional measure of stereotypic thinking were embedded within a variety of other questionnaires in the packet, identical across conditions, that were ostensibly being used for another project. The mortality salience treatment consisted of the same questionnaire used in Study 1. However, in an effort to assess the specificity of the effects on stereotype usage to thoughts of death as opposed to other aversive topics, control participants completed parallel questions with respect to experiencing dental pain.

The attributional measure of stereotyping was placed at the end of the packet such that participants would have completed the stereotyping measure approximately $7 \mathrm{~min}$ after the mortality salience manipulation. The attributional measure of stereotypic thinking used in Study 2 was developed by von Hippel et al. (1997). The measure contains 22 sentence stems depicting 10 gender-neutral behaviors (e.g., Laura ate a sandwich), 6 stereotype-consistent female behaviors (e.g., Katherine baby-sat the neighbor's kids), and 6 stereotype-consistent male behaviors (e.g., Tom paid for their dinner) and asks participants to complete the sentences with any words they like as long as the result is a grammatically correct sentence. Of the 6 stereotype-consistent male and female behaviors, 3 were paired with a female name, and 3 were paired with a male name. Thus, participants were given the opportunity to explain both stereotype-consistent and stereotype-inconsistent behaviors.

\section{Results and Discussion}

The attributional measure of stereotypic thinking was scored as in von Hippel et al. (1997) by two independent raters who were unaware of conditions. Each rater scored the gender-relevant sentence completions as being either explanatory or nonexplanatory in nature (the raters initially had $84 \%$ agreement and resolved discrepancies through discussion). An example of an explanatory sentence completion for the sentence stem "Mary paid for dinner" would be "because her boyfriend forgot his wallet." An example of a nonexplanatory completion for the same stem would be "on a Saturday night." Also following von Hippel et al. (1997), the primary dependent measure was a composite difference score computed by subtracting the number of explanations provided for stereotype-consistent behaviors from the number of explanations offered for stereotype-inconsistent behaviors (specifically, the number of explanations of males engaging in male behaviors was subtracted from the number of explanations of females engaging in male behaviors and averaged with the number of explanations of females engaging in female behaviors subtracted from the number of explanations of males engaging in female behaviors). Thus, higher scores indicate a greater tendency to explain stereotypeinconsistent than stereotype-consistent behaviors, thereby indicating increased stereotypic thinking (von Hippel et al., 1997).

Stereotyping. As predicted, mortality salient participants showed a greater tendency to explain stereotype-inconsistent behaviors $(M=0.34)$ than did dental pain participants $(M=-0.08)$, $t(61)=2.26, p<.05$. To more fully explain this effect, we also analyzed our primary dependent measure in a 2 (mortality salience: death vs. dental pain) $\times 2$ (explanations: stereotype consistent vs. stereotype inconsistent) ANOVA with the latter variable treated as a repeated measures variable. This analysis revealed a significant interaction, $F(1,59)=5.08, p<.03$. Pairwise comparisons showed that mortality salient participants gave more explanations for stereotype-inconsistent items $(M=2.10)$ than stereotype-consistent items $(M=1.41), t(59)=2.20, p<.05$. When mortality was not salient, there was a slight tendency for participants to give more explanations for stereotype-consistent than stereotype-inconsistent behavior ( $M=1.94$ vs. 1.78 ), but this difference did not approach statistical significance, $t(59)=1.23$, $p>.25$. Cell means are presented in Table 2 .

Supplemental analyses. Another unique aspect of this study was that participants were responding to behaviors of their own group as well as an out-group. One question that can be addressed is whether the female mortality salient participants were prone to stereotypic thinking only about the males or about fellow females as well. When the gender of the target was included as a withinsubject variable in an ANOVA, results revealed a main effect for mortality salience, $F(1,59)=5.08, p<.03$, but no interaction between mortality salience and gender of target, $F(1,59)=1.55$, $p>.21$. Thus, the female participants were just as likely to use more explanatory continuations for female-inconsistent relative to female-consistent behaviors as they were for male-inconsistent relative to male-consistent behaviors.

We also tested to see whether our female participants would provide relatively more stereotype-inconsistent explanations for male behaviors or female behaviors. If mortality salience leads to an increase in stereotypic thinking, we would expect similar results for both male and female behaviors. To test this possibility, we created a measure of preference for stereotype-inconsistent explanations for male behaviors by subtracting the number of explanations made for males engaging in male behaviors from females engaging in male behaviors. We created a measure of preference for stereotype-inconsistent explanations given for female behaviors by subtracting the number of explanations for females engaging in female behaviors from males engaging in female behaviors. Thus, this measure breaks down the composite score we computed for the first analysis we reported by male versus female behaviors. We then submitted these measures to a 2 (mortality salience: death vs. dental pain) $\times 2$ (explanations: male behaviors vs. female behaviors) mixed ANOVA. This analysis revealed a main effect of mortality salience, $F(1,59)=5.08, p<.03$, indicating that mortality salient participants gave more explanations for both female and male stereotype-inconsistent behaviors than did control

\footnotetext{
${ }^{5}$ Only female students took part in this study because there was not a sufficient number of male students in the participant pool at the time the study was run to yield an informative analysis of gender effects.
} 
Table 2

Cell Means for the Two-Way Interaction Between Mortality

Salience and Stereotype Consistency on Explanatory

Completions of Sentence Stems in Study 2

\begin{tabular}{lcccccc}
\hline & \multicolumn{2}{c}{ Mortality salient } & & \multicolumn{2}{c}{ Dental pain } \\
\cline { 2 - 3 } \cline { 5 - 6 } \multicolumn{1}{c}{ Explanation } & $M$ & & $S D$ & & $M$ & $S D$ \\
\hline Stereotype consistent & $1.41_{\mathrm{a}}$ & 1.40 & & $1.94_{\mathrm{b}}$ & 1.44 \\
Stereotype inconsistent & $2.10_{\mathrm{b}}$ & 1.61 & & $1.78_{\mathrm{b}}$ & 1.43 \\
\hline
\end{tabular}

Note. Cell means that do not share a common subscript differ at $p<.05$. A higher number reflects a higher number of explanatory sentence completions.

participants ( $M \mathrm{~s}=0.34$ and -0.08 , respectively). There was also a main effect of behavior, $F(1,59)=4.02, p<.05$, showing that, overall, more stereotype-inconsistent explanations were made for female behaviors than for male behaviors $(M \mathrm{~s}=0.32$ and -0.06 , respectively). However, there was no significant interaction, indicating that our female participants did not differ as a function of mortality salience in the number of explanations they generated for male-inconsistent behaviors or female-inconsistent behaviors.

These results conceptually replicate the findings of Study 1 with a different dependent measure of stereotypic thinking and extend them to a different type of stereotype. Participants who were reminded of their mortality were more likely than control participants to generate explanatory continuations for genderinconsistent behaviors than for gender-consistent behaviors. Presumably, mortality salient participants had a greater need to uphold their stereotypes concerning male and female gender roles and, therefore, were more likely to explain and make sense out of information that disconfirmed their stereotypes about gender. The fact that mortality salience led to an increase in participants' tendency to explain stereotype-inconsistent behavior offers further evidence that the terror management function of stereotyping does not necessarily entail derogation of those who threaten one's worldview; rather, it can involve viewing such individuals in a way that confirms their stereotypes and ultimately their cultural conception of reality. The fact that mortality salience led to increased use of stereotypes concerning gender extends the TMT analysis of stereotypes beyond the ethnic and religious out-groups that have been studied in past research. Taken together, the results of Study 1 and Study 2 provide evidence that mortality salience increases stereotyping and thus suggest that stereotypes serve a terror management function.

\section{Study 3}

If reminders of mortality lead people toward a stereotypic view of others, then such reminders might also lead to a preference for those who conform to the stereotype of their group over those who deviate from that stereotype. To the extent that stereotypes concerning out-groups are part of the cultural worldview, out-group members who confirm these stereotypes provide validation for the cultural worldview, and out-group members who disconfirm these stereotypes threaten this conception. Thus, when need for faith in one's worldview is high, people may actually prefer out-group members who are highly different from the in-group over outgroup members who are more similar.

Perhaps similar reasoning can help account for the relative popularity of and affection for fictional figures such as Amos and Andy; Jack Benny's sidekick, Rochester; and actors such as Stephen Fetchitt among White Americans in the middle part of this century, a time when many Whites felt little compunction about openly expressing their disdain for Blacks. In a more contemporary vein, this reasoning may help account for the popularity of streetwise African American hustler characters portrayed in such films as Trading Places, Booty Call, and Rush Hour. More generally, a tendency to prefer members of out-groups who conform to stereotypes might help explain the modern-day racists who fear and dislike African Americans but nonetheless admire and idolize well-known Black athletes, musicians, and entertainers. Reactions to the O. J. Simpson murder case may provide a particularly poignant example in which preference for stereotype-consistent behavior by an African American, however terrible, may have been evident. We have heard avowed racists on call-in talk shows telling hosts in satisfied tones that "even if you dress Black people up and they learn to talk White, their true nature will eventually surface." Viewing a once-popular and respected African American as a violent murderer may have helped some White Americans sustain faith in their bigoted worldviews.

A good deal of research suggests, however, that people typically prefer out-group members who are similar to themselves and thus disconfirm the stereotype of the out-group over out-group members who are dissimilar to themselves and thus confirm the stereotype. Some of the earliest evidence on this issue comes from studies conducted to determine whether out-group derogation results primarily from the belief that out-group members are different in attitudes and values from in-group members, a view discussed by Allport (1954), Rokeach (1960), and Sears and McConahay (1973). For example, Sears and McConahay argued that a great deal of racism stems from the belief that African Americans have fundamentally different values than White Americans and thus are a threat to the White American way of life. In these early studies, White participants were exposed to a Black person who appeared either similar or dissimilar to themselves. In a number of cases, this similarity manipulation was very close to making a Black person's behavior either similar to the Black stereotype or more similar to the White stereotype.

For example, Rosenfield, Greenberg, Folger, and Borys (1982) found that an encounter with a Black panhandler, who presumably confirmed some racial stereotypes, led White participants to have less interest in "Interracial Brotherhood Week" than did an encounter with a conservatively dressed Black graduate student who appeared similar to the White stereotype. In a recent study, Jussim, Fleming, Coleman, and Kohberger (1996; see also Jussim et al., 1987) had a Black confederate speak either unaccented standard White English or with an African American accent. Whereas White participants liked the "Black-sounding" Black confederate much less than a White confederate, they liked a "Whitesounding" Black confederate just as much as the White confederate. According to Jussim and colleagues (1996), this preference for the "White-sounding" Black confederate over the stereotypeconsistent Black confederate is best explained by the integration of three different theories regarding how stereotypes influence person 
perception: assumed characteristics theory, evaluative extremity theories, and expectancy violation theory.

Assumed characteristics theory posits that in-group members generally evaluate their own group more positively because they assume that members of their own group have more favorable characteristics. Thus, in the absence of any other information about a particular out-group member, in-group members will show less bias against the out-group member if the person acts and appears similar to the in-group (e.g., Locksley, Borgida, Brekke, \& Hepburn, 1980; Rokeach \& Mezei, 1966). In a related vein, evaluative extremity theories argue that a pattern of extreme reactions to out-group members can be explained by an attitude of ambivalence that Whites may have toward Blacks (Hass et al., 1991; Katz \& Hass, 1988). From this perspective, extreme positive and negative reactions that Whites have toward Blacks result from Whites simultaneously holding negative-deviant attitudes and positivesympathetic attitudes toward Blacks. This ambivalence gives rise to extreme reactions when Blacks are encountered in a positive or negative social context. A similar pattern of extreme reactions can be explained by expectancy violation theory (e.g., Bettencourt, Dill, Greathouse, Charlton, \& Mulholland, 1997; Jackson, Sullivan, \& Hodge, 1993; Jussim et al., 1987). Expectancy violation theory posits that in-group members use a judgment process similar to Kelley's (1971) discounting and augmenting principle when perceiving out-group members. For example, a Black individual who earns a college degree and obtains a high-paying job might be perceived as especially successful because Whites assume that Blacks have had to overcome many obstacles to achieve success (e.g., racism and discrimination). These obstacles are perceived as inhibiting factors that augment Whites' evaluations of Blacks who are successful. Thus, an out-group member who is perceived as engaging in a positive, unexpected behavior would be evaluated extremely positively by in-group members.

In sum, these theoretical accounts suggest that in-group members generally prefer stereotype-disconfirming out-group members because of simple judgments of similarity (see Jussim et al., 1996, for a review), ambivalent attitudes (Hass et al., 1991; Katz \& Hass, 1988), and expectancy violations (e.g., Bettencourt et al., 1997; Jackson et al., 1993; Jussim et al., 1987). In contrast, TMT leads to the hypothesis that stereotype-consistent out-group members are likely to be preferred over stereotype-inconsistent out-group members when individuals are particularly concerned about sustaining faith in their basic views of the world. As terror management research indicates, people are especially likely to be concerned with sustaining faith in their worldviews when thoughts of mortality are salient (e.g., Greenberg et al., 1990, 1994; Pyszczynski et al., 1996). Thus in Study 3, we tested the hypothesis that mortality salience would increase participants' liking for a stereotypeconfirming out-group member and decrease their liking for a stereotype-disconfirming out-group member.

Assessing degree of liking for stereotyped out-group members enabled us to extend our analysis to the prescriptive component of stereotypes (cf. Burgess \& Borgida, in press; Eagly, 1987; Spence $\&$ Helmreich, 1978). Whereas the descriptive component of stereotypes reflects beliefs about characteristics that the out-group possesses, the prescriptive component of stereotypes reflects beliefs about the characteristics that out-group members should possess and the roles they should fulfill in society. Thus, whereas the beliefs that African Americans are unintelligent, athletic, and lazy are desscriptive, the beliefs that African Americans should avoid intellectual pursuits, play basketball, and have lower paying jobs are prescriptive. Burgess and Borgida (in press) have argued that descriptive and prescriptive components of stereotypes lead to different forms of discrimination and reactions to out-group members. Whereas the descriptive component might lead Whites to make certain assumptions about individual African Americans, the prescriptive component might lead Whites to dislike African American individuals who do not conform to the "Black" stereotype. From this perspective, Studies 1 and 2 can be viewed as showing that mortality salience influences the descriptive component of stereotyping (for Germans and males and females, respectively). Burgess and Borgida's analysis suggests that the prescriptive component of stereotypes will be reflected in a preference for stereotype-consistent out-group members over stereotypeinconsistent ones. Thus, in Study 3 and the remaining studies, we assessed liking for the out-group target persons to extend our analysis to the prescriptive component of stereotyping.

Participants were induced to think about either their own death or a neutral topic and were then asked to evaluate a Black person who conformed to the stereotype, violated the stereotype, or did neither. We predicted that although, as in past research (Jussim et al., 1996; Rokeach, 1960; Rosenfield et al., 1982; Sears \& McConahay, 1973), mortality nonsalient participants would typically prefer the stereotype-inconsistent Black over the stereotypeconsistent Black, mortality salience would reverse this preference, leading to increased liking for the stereotype-consistent Black and decreased liking for the stereotype-inconsistent Black.

\section{Method}

Participants. Participants were 28 male and 48 female White undergraduate students enrolled in introductory psychology classes at the University of Arizona who took part in this research for partial course credit. Five participants, roughly evenly distributed across conditions, were dropped for reporting suspicion about the confederate, leaving a sample of 25 men and 46 women.

Procedure. Participants completed the experiment in groups of 3 to 4 and were randomly assigned to conditions in a 2 (mortality salience: death vs. television) $\times 3$ (Black confederate: stereotype consistent vs. stereotype inconsistent vs. stereotype neutral) between-groups design. Participants waited outside the laboratory with a Black male confederate posing as a fellow participant. The experimenter led the participants and confederate into the laboratory and then explained that the study was concerned with the relationship between personality traits and first impressions of people. Participants were told that they would write a brief essay that would be circulated such that each participant would read two essays and complete some personality trait ratings of the persons who wrote them. They then signed a consent form and were ushered into individual cubicles to ensure anonymity and privacy. Participants first wrote a brief essay about what they did over the summer and folded it in half with the writing on the inside. The experimenter then collected the essays and passed out the packet of questionnaires, which included the mortality salience manipulation (the experimenter was unaware of the manipulation). Next the experimenter passed out the essays for the participants to read and evaluate. Each participant always received one essay supposedly written by a White man and one essay supposedly written by a Black man. Participants were then given a form to evaluate the author of the first essay and an envelope in which to put the form to ensure privacy. After participants rated the first essay, the experimenter collected the envelope and passed out the second essay. The second essay was then collected, and a second evaluation form and envelope were distributed. The order in which participants received the 
Table 3

Cell Means for the Three-Way Mortality Salience $\times$ Confederate $\times$ Ethnicity Interaction on Target Liking and Desire to Meet the Target in Study 3

\begin{tabular}{|c|c|c|c|c|c|c|c|c|}
\hline \multirow[b]{4}{*}{ Confederate } & \multicolumn{8}{|c|}{ Ethnicity of target } \\
\hline & \multicolumn{4}{|c|}{ Black } & \multicolumn{4}{|c|}{ White } \\
\hline & \multicolumn{2}{|c|}{$\begin{array}{l}\text { Mortality } \\
\text { salient }\end{array}$} & \multicolumn{2}{|c|}{$T V$} & \multicolumn{2}{|c|}{$\begin{array}{l}\text { Mortality } \\
\text { salient }\end{array}$} & \multicolumn{2}{|c|}{ TV } \\
\hline & $M$ & $S D$ & $M$ & $S D$ & $M$ & $S D$ & $M$ & $S D$ \\
\hline Stereotype consistent & $7.86_{\mathrm{a}}$ & 0.63 & $2.69_{b}$ & 1.63 & $4.86_{c}$ & 1.73 & $5.00_{c}$ & 1.04 \\
\hline Neutral & $5.81_{\mathrm{c}}^{\mathrm{a}}$ & 0.98 & $5.20_{\mathrm{c}}$ & 1.09 & $5.68_{c}$ & 1.79 & $5.54_{c}$ & 1.11 \\
\hline Stereotype inconsistent & $4.36_{c}$ & 0.83 & $7.15_{\mathrm{a}}$ & 1.91 & $5.32_{\mathrm{c}}$ & 1.10 & $5.11_{\mathrm{c}}$ & 1.45 \\
\hline
\end{tabular}

Note. Means that do not share a common subscript differ at $p<.05$ (two-tailed) within conditions. Scores could range from 1 (negative response) to 9 (positive response).

White-authored and Black-authored essays was counterbalanced. After completing the second evaluation and again sealing it in an envelope, participants returned to the main room, where they were thoroughly debriefed.

Materials. The packet of questionnaires contained two filler personality measures, the mortality salience manipulation, and the PANAS-X (Watson et al., 1988). The mortality salience manipulation consisted of the same two open-ended questions about either death or watching television used in Study 1.

The stereotypicality manipulation consisted of variations in how the African American confederate was dressed and how he described his summer activities in the prepared essay. The appropriate essay was always readily attributable to the confederate because, in each case, it began by referring to how few Black students (or, in the stereotype-consistent condition, "brothers") live in Tucson. The White essay was always one of the two neutral essays described subsequently.

In the stereotype-consistent condition, the portrayal was based both on prior research findings (Devine \& Baker, 1991; Jussim et al., 1996; Rosenfield et al., 1982) and on media portrayals of African Americans from music videos and films. The confederate wore untied high-top sneakers, an Atlanta Braves shirt, low-worn black shorts, dark sunglasses, and a backward baseball cap. In addition, he carried a portable cassette player and had headphones around his neck. The essay that appeared to be written by the confederate in this condition referred to "brothers, splitting to L.A., serious hoop, slammin' nightlife, cruisin' for honeys, clubbing, getting stupid, a few run-ins, drinking forties" and ended with "Man coming back to classes was whack, but I don't want to trip on that."

In the stereotype-inconsistent condition, the confederate dressed conservatively, wearing a button-down light blue dress shirt and tie with khaki dress pants, penny-loafers, and black framed glasses. In addition, he carried a briefcase. The stereotype-inconsistent essay included no colloquial expressions and stated that the confederate had stayed in Tucson, taking $9 \mathrm{hr}$ of summer engineering classes; that he worked $20 \mathrm{hr}$ a week for a software company; and that he had read both volumes of Herman Wouk's War and Remembrance. This essay also stated that he spent his spare time playing chess, and it ended as follows: "All in all, I had a very productive and exciting summer."

Finally, in the neutral condition, the confederate dressed like the typical student on campus, in a casual T-shirt, shorts, and low-top sneakers, and he carried a backpack over one shoulder. There were two versions of the neutral essay; each was used half the time for the White target, and the other essay was used for the neutral African American target. One of the essays described traveling to San Francisco (thanks to the target's mom working for United Airlines); seeing the sights; visiting family in Columbus, Ohio; and going to New Orleans for a friend's wedding. It ended with
"We had a bachelor's party the night before on Bourbon street. It was a blast." The other neutral essay referred to being stuck in Tucson, working as a lifeguard, taking one class, hanging out with friends, going to parties, watching videos, playing board games, and writing to a friend in Chicago. It ended with "By the way, I was the Monopoly champ of the summer."

The primary dependent measure of evaluation of the target person consisted of two questions: "How much do you think you would like this person?" and "How interested would you be in getting to know the person?" These questions were responded to on 9-point scales ranging from not at all (1) to totally (9). These questions were followed by 12 traits that participants rated for applicability to the essay author on the same type of 9-point scale. The traits were intelitigent, conceited, nice, arrogant, antisocial, trustworthy, hostile, hardworking, hypocritical, friendly, freeloader, and productive.

\section{Results and Discussion}

Unless otherwise specified, data were analyzed in 2 (mortality salience: death vs. television) $\times 3$ (Black confederate: stereotype consistent vs. stereotype inconsistent vs. neutral) $\times 2$ (ethnicity of target: Black vs. White) ANOVAs with ethnicity of target as a repeated measures variable. There were two primary dependent measures: liking for the target and a composite of positive and negative traits attributed to the target.

Liking for the target. We combined the first two questions regarding the extent to which participants liked and desired to meet the target to form a composite measure of attraction. ${ }^{6}$ The ANOVA revealed a main effect of mortality salience, $F(1$, $65)=5.14, p<.05$, along with two-way interactions for both mortality salience and stereotypicality of confederate, $F(1$, $65)=22.29, p<.01$, and mortality salience and ethnicity of target, $F(1,65)=4.50, p<.05$. These effects were qualified by the predicted three-way interaction of mortality salience, stereotypicality of confederate, and ethnicity of target, $F(1,65)=33.62$, $p<.001$. Cell means for the three-way interaction are presented in Table 3.

\footnotetext{
${ }^{6}$ When analyzed separately, both items revealed similar significant interaction patterns and so were combined in an effort to condense the results. The Mortality Salience $\times$ Confederate $\times$ Ethnicity interactions were as follows: $F(1,65)=18.80, p<.01$, for the liking item and $F(1$, $65)=22.59, p<.001$, for the desire to meet item.
} 
Pairwise comparisons between mortality salient and control conditions revealed that (a) mortality salience led to a significant increase in liking for the stereotype-consistent Black confederate, $t(65)=8.76, p<.01$; (b) mortality salience led to a significant decrease in liking for the stereotype-inconsistent Black confederate, $t(65)=4.72, p<.01$; (c) mortality salience did not affect liking for the neutral Black confederate, $t<1.0$; and (d) mortality salience did not affect liking for the White target. Pairwise comparisons within the television control conditions revealed a pattern similar to that found in many previous studies (e.g., Jussim et al., 1996): Participants liked the confederate significantly more when he disconfirmed the stereotype than when he confirmed it, $t(65)=7.55, p<.01$, or was neutral, $t(65)=3.30, p<.01$. Participants were also more attracted to the stereotype-neutral confederate than the stereotype-consistent target, $t(65)=4.25, p<$ .01 . There were no effects of the stereotypicality of the Black confederate on liking for the White target.

As predicted, pairwise comparisons within the mortality salient conditions produced the opposite pattern and revealed significantly more liking for the stereotype-consistent than the stereotypeinconsistent Black confederate, $t(65)=5.93, p<.01$, or stereotype-neutral Black confederate, $t(65)=3.45, p<.01$. Mortality salient participants also tended to like the stereotypeinconsistent Black confederate less than the stereotype-neutral Black confederate, $t(65)=1.97, p<.06$. There were no effects of confederate stereotypicality on liking for the White target.

Positive and negative traits. A composite measure of favorability of trait attributions was computed by reversing the ratings on the negative traits, adding these to the ratings on the positive traits, and dividing by the number of traits. An ANOVA on this composite revealed a main effect for confederate stereotypicality, $F(1,65)=9.42, p<.01$, as well as a Mortality Salience $\times$ Confederate Stereotypicality interaction, $F(1,65)=9.58, p<.05$. These effects were qualified, however, by the predicted three-way Mortality Salience $\times$ Confederate Stereotypicality $\times$ Ethnicity of Target interaction, $F(1,65)=20.16, p<.001$. Cell means for the three-way interaction are presented in Table 4.

The pattern of means on trait attributions mirrored the pattern found on liking. Pairwise comparisons between mortality salience and control conditions revealed that (a) mortality salience led to more favorable trait ratings for the Black confederate when he was stereotype consistent, $t(65)=4.74, p<.01$; (b) mortality salience led to less favorable trait ratings of the Black confederate when he was stereotype inconsistent, $t(65)=4.09, p<.01$; (c) mortality salience did not affect trait ratings for the stereotype-neutral Black confederate $(p>.25)$; and (d) mortality salience did not affect trait ratings of the White target (all $p s>.25$ ).

Pairwise comparisons within the control conditions again revealed that the stereotype-inconsistent Black confederate was seen more positively than the stereotype-consistent Black confederate, $t(65)=6.27, p<.01$, and nonreliably more positively than the stereotype-neutral Black confederate, $t(65)=1.72, p<.12$. Control participants also rated the stereotype-neutral Black confederate more favorably than the stereotype-consistent Black confederate, $t(65)=4.55, p<.01$. There were no effects of Black confederate stereotypicality on ratings of the White target.

Pairwise comparisons within the mortality salient conditions again revealed a pattern opposite to that found in the control conditions: Participants made significantly more favorable trait ratings of the Black confederate when he was stereotype consistent than when he was stereotype inconsistent, $t(65)=2.56, p<.05$. Participants also rated the stereotype-neutral Black confederate marginally more favorably than the stereotype-inconsistent Black confederate, $t(65)=1.89, p<.07$. Finally, mortality salient participants did not rate the stereotype-consistent Black confederate as significantly different from the stereotype-neutral Black confederate. There were no effects of confederate stereotypicality on ratings of the White target, except between the stereotypeconsistent and stereotype-neutral confederate conditions. This comparison showed that when the Black confederate was stereotype consistent, mortality salient participants were less favorable to the White target than when the Black confederate was stereotype neutral, $t(65)=2.45, p<.05$.

The findings from Study 3 replicate previous research showing that in-group members (White participants) generally prefer stereotype-inconsistent out-group members (i.e., Black targets) over stereotype-consistent ones (Jussim et al., 1996; Rosenfield et al., 1982). However, Study 3 also demonstrated that, when thoughts of their mortality were salient, participants showed the opposite pattern of increased liking for the stereotype-consistent out-group member and decreased liking for the stereotypeinconsistent out-group member. These findings support our contention that stereotypes, as part of the cultural worldview, serve a terror management function.

Table 4

Cell Means for the Three-Way Mortality Salience $\times$ Confederate $\times$ Ethnicity Interaction on Trait Ratings of Favorability in Study 3

\begin{tabular}{|c|c|c|c|c|c|c|c|c|}
\hline \multirow[b]{4}{*}{ Confederate } & \multicolumn{8}{|c|}{ Ethnicity of target } \\
\hline & \multicolumn{4}{|c|}{ Black } & \multicolumn{4}{|c|}{ White } \\
\hline & \multicolumn{2}{|c|}{ Mortality salient } & \multicolumn{2}{|c|}{$\mathrm{TV}$} & \multicolumn{2}{|c|}{ Mortality salient } & \multicolumn{2}{|c|}{ TV } \\
\hline & $M$ & $S D$ & $M$ & $S D$ & $M$ & $S D$ & $M$ & $S D$ \\
\hline Stereotype consistent & $5.48 \mathrm{a}$ & 1.51 & $3.08_{\mathrm{b}}$ & 0.99 & $4.44_{\mathrm{a}}$ & 1.57 & $4.60_{\mathrm{a}, \mathrm{b}}$ & 1.07 \\
\hline Stereotype neutral & $5.14_{a, b}$ & 0.87 & $5.38_{\mathrm{a}, \mathrm{c}}$ & 0.95 & $5.69_{\mathrm{b}}^{\mathrm{a}}$ & 0.73 & $5.52_{\mathrm{a}, \mathrm{b}}$ & 1.03 \\
\hline Stereotype inconsistent & $4.18_{\mathrm{b}}$ & 0.85 & $6.25_{\mathrm{a}}$ & 1.24 & $5.13_{\mathrm{a}, \mathrm{b}}$ & 0.87 & $5.1 l_{a, b}$ & 0.62 \\
\hline
\end{tabular}

Note. Means that do not share at least one common subscript within ethnicity of target differ at $p<.05$ (two-tailed) within conditions. Scores could range from 1 (very low favorability) to 9 (very high favorability). 
Could there be other explanations of the findings of Study 3 ? Perhaps attraction to the stereotype-inconsistent Black confederate was influenced by his appearing to be somewhat "nerdish" or to be an "Oreo" (Black on the outside, White on the inside). His conservative style of dress, rather formal language, and apparently studious and hardworking nature may have led to ambivalent reactions in some participants regardless of his race. It could be argued that mortality salience brought out these relatively subtle feelings and led to decreased attraction for reasons unrelated to the confederate's race. It is not entirely clear, however, what that reason would be. In addition, this explanation could not account for the increased attraction to the stereotype-consistent Black confederate that was also found.

It could also be argued that the effects of Study 3 occurred because mortality salience led to an increased desire to be "politically correct" and accepting of cultural differences rather than because the nature of the confederate's behavior confirmed or disconfirmed participants' worldviews. To the extent that participants were committed to a view of themselves as non-racist, open-minded, and egalitarian, it may be that mortality salience increased their need to live up to these self-conceptions. Although this might explain the increased liking for the stereotype-consistent Black confederate, it would not account for the decreased liking for the stereotype-inconsistent Black confederate. A commitment to open-mindedness would certainly not lead to more negative evaluations of a Black person, no matter how "bookish" he appeared to be.

\section{Study 4}

Although the "nerd negativity" and "political correctness" alternative explanations might each help account for a portion of the findings of Study 3, it seems unlikely that both processes would be operating simultaneously in this design or that either one could account for the full pattern of results. Nonetheless, we wanted to rule out these possibilities and extend the generality of the findings of Study 3 to stereotypes of other groups. Therefore, we performed a conceptual replication of this study in which reactions to stereotype-consistent and stereotype-inconsistent members of groups were examined in a situation in which the stereotypeinconsistent behavior was not likely to be viewed as "nerdish" and political correctness was less likely to play a role. Specifically, Study 4 examined the effects of mortality salience on attraction to men and women who either conform to or deviate from traditional gender stereotypes for occupation, following procedures developed by Bettencourt et al. (1997).

An additional purpose of Study 4 was to more clearly show that the effects obtained in the present research are specific to the problem of death rather than a response to thoughts of aversive events in general. Although previous research has shown that effects parallel to those of mortality salience are not obtained in response to thoughts of the meaninglessness of life, giving a speech in front of a large audience, becoming paralyzed, general worries about life after college, taking or failing an important exam, or actually experiencing failure on a supposed intelligence test, the present findings of increased use of stereotypes and increased liking for stereotype-confirming others are different from the findings of previous mortality salience studies. Although Study 2 showed that mortality salience affects stereotype usage differently than thoughts of dental pain, we deemed it important to show that the increase in liking for stereotype-confirming others is also unique to mortality salience. Baumeister and Tice (1990) and Leary, Tambor, Terdal, and Downs (1995) have suggested that the fear of social exclusion may be a fundamental human concern; therefore, we directly compared the effects of thoughts of one's own death with those of thoughts of social exclusion in Study 4.

\section{Method}

Participants. The participants were 76 female undergraduate students enrolled in introductory psychology at the University of Arizona who took part in exchange for partial course credit.

Procedure. Participants completed the experiment in groups of 3 to 5 and were randomly assigned to conditions in a 2 (mortality salience: death vs. social exclusion) $\times 2$ (target: stereotype consistent vs. stereotype inconsistent) between-groups design. As in previous mortality salience studies (e.g., Greenberg, Simon, et al., 1992; Simon, Greenberg, HarmonJones, et al., 1997), the experimenter began each session by explaining to the participants that "they would take part in two short studies, since technically, they had to stay for a full hour to get credit." The experimenter told participants that the first study was designed to investigate "how different types of personality traits go together in people." The experimenter explained further that "in the second study, we are working with some faculty in the Department of Journalism to determine what types of resume styles are most effective in the field of news writing." The experimenter assured anonymity of participants' responses on all of the questionnaires, led them into private cubicles, and administered the first packet of personality questionnaires, which contained the mortality salience manipulation.

After completion of the first packet, the experimenter instructed the participants to come out of the cubicles to receive instructions for the second study. The instructions that followed informed participants that "We obtained some resumes from a business here in Tucson that you will have a chance to look through. Then we will give you the opportunity to make some judgments about the resume and the job candidate; only the names of the candidates have been changed to protect their identity." 'The experimenter also explained, "Because it is becoming more common for applicants to include pictures of themselves in their resumes, we decided to have you evaluate candidates who included pictures with their resumes." As in Bettencourt et al. (1997), the experimenter instructed participants to take the role of the employer when viewing the candidate's resume. Participants were then led back into the cubicles and given a second packet that included the resume and some questions asking them to rate the candidate on several dimensions. After participants were finished with the packet, the experimenter came to each cubicle with a final page of questions about the job candidate that served as manipulation checks. On completion of the second study, participants were debriefed, thanked for their participation, given credit, and dismissed.

Materials. The packet of personality questionnaires for "Study 1" contained two filler personality scales, the mortality salience manipulation, and the PANAS-X (Watson et al., 1988). The mortality salience manipulation consisted of the same two open-ended questions about death used in the previous studies, which were contrasted with parallel questions in the control condition about being socially excluded. Like the dental pain control condition used in Study 2, the social exclusion control was used as a more rigorous test of our hypothesis that participants' increase in stereotypic thinking is produced by reminders of mortality and not by reminders of other aversive events. The open-ended social exclusion items asked participants to "Briefly describe the thoughts and emotions that the thought of being socially excluded by your circle of friends arouses in you" and "Please describe in as much detail as possible what you think will happen to you as you are socially rejected (against your desires) by your circle of friends." 
The packet for "Study 2" contained a neatly typed resume, a picture of the candidate, and a page of questions about the candidate. The information presented in the resume was identical to the information used in Bettencourt et al. (1997, Study 3) and was the same in all versions of the resumes. This candidate information included the following: Education was a BA in journalism; work experiences were reporter and editor positions at one large newspaper and two local newspapers, as well as food server at a restaurant; and qualifications were listed as excellent ability to communicate through writing and experience in many facets of newspaper production. There was also a section on personal information that described the candidate as married (with a female-named spouse for the male target and a male-named spouse for the female target), adventure seeking, and interested in hiking and mystery novels. The gender of the candidate was manipulated by the names on the resumes (i.e., Thomas A. Johnson or Tonya A. Johnson) and by pictures of the candidates that were included in the resume packet. ${ }^{7}$ The target's job objective in the resume was listed as either a "fashion writer covering women's apparel and jewelry" or a "sports writer covering men's basketball and football." Thus, the stereotype-consistent conditions were the female fashion writer and the male sports writer, and the stereotype-inconsistent conditions were the female sports writer and the male fashion writer.

The last page in the resume packet asked participants to rate the candidate on three favorability items. Each item consisted of a 6-point Likerttype scale with 1 being the positive end of the scale and 6 being the negative end of the scale. The items asked participants to evaluate the candidate as good-bad, favorable-unfavorable, and capable-uncapable. Bettencourt et al. (1997) used the same three items but also included a creative-uncreative item. We did not include this item because pilot testing revealed that it was not correlated with the other three items. The reason was presumably that our cover story asked participants to evaluate the style of the resumes, and so this question reflected participants' evaluation of the appearance of the resumes and not their evaluation of the candidate. The manipulation check questions asked participants the following: "To what extent was this candidate's job objective expected/unexpected?" and "To what extent did this candidate's job objective fit the stereotype for gender?" Participants responded to these questions on 4-point Likert-type scales ranging from very expected (1) to very unexpected (4) and from fits stereotype (1) to does not fit stereotype (4).

\section{Results and Discussion}

Unless otherwise specified, results were analyzed in 2 (mortality salience: death vs. social exclusion) $\times 2$ (target: consistent vs. inconsistent) between-groups ANOVAs. Initial analyses including sex of target as a variable revealed no effects or interactions involving sex. Thus, the male stereotype-consistent and female stereotype-consistent targets were collapsed across conditions, along with the male stereotype-inconsistent and female stereotypeinconsistent targets. These collapsed conditions were distributed roughly evenly within each of the four conditions. The primary dependent variable in this study was favorability ratings of the target person.

Manipulation checks. The manipulation check questions were reverse scored so that higher scores reflected higher perceived stereotypicality of the target. An ANOVA performed on participants' ratings of the extent to which the candidate's job objective fit the gender stereotype revealed only a main effect of stereotypicality of target, $F(1,73)=33.94, p<.001$, indicating that the stereotype-inconsistent targets' job objective was perceived as less stereotypic than the stereotype-consistent targets' job objective $(M=2.00$ vs. 3.28$)$. A parallel ANOVA performed on participants' ratings of the extent to which the candidate's job objective
Table 5

Cell Means for the Two-Way Interaction of Mortality Salience and Stereotypicality of Target on the Composite Measure of Favorability of Impressions of Job Applicants in Study 4

\begin{tabular}{lccccc}
\hline & \multicolumn{2}{c}{ Mortality salient } & & \multicolumn{2}{c}{ Exclusion } \\
\cline { 2 - 3 } \cline { 5 - 6 } Stereotypicality target & $M$ & $S D$ & & $M$ & $S D$ \\
\hline Stereotype consistent & $5.24_{\mathrm{a}}$ & 0.57 & & $4.46_{\mathrm{b}}$ & 0.88 \\
Stereotype inconsistent & $4.90_{\mathrm{a}}$ & 0.99 & & $5.14_{\mathrm{a}}$ & 0.65 \\
\hline
\end{tabular}

Note. Means that do not share a common subscript differ at $p<.05$. Higher scores reflect more favorable ratings.

was expected revealed no significant effects, but there was a trend toward a main effect of stereotypicality of target in the same direction, $F(1,73)=2.69, p<.11(M=2.93$ vs. 3.19$)$.

Favorability of impressions measure. A composite measure of favorability of impressions of the target was constructed by reverse scoring the three items, summing them, and then dividing by the number of items. The two-way ANOVA revealed only the predicted interaction, $F(1,73)=8.07, p<.01$. Pairwise comparisons between mortality salience and control conditions revealed that mortality salience led to significantly more favorable ratings for the stereotype-consistent targets, $t(73)=2.92, p<.01$, and a nonsignificant trend toward less favorable ratings for the stereotype-inconsistent target, $t(73)=1.04, p>.30$. Pairwise comparisons within the social exclusion control conditions replicated Bettencourt et al.'s (1997) finding of more favorable ratings for the stereotype-inconsistent targets over the stereotypeconsistent targets, $t(73)=2.63, p<.05$. The pattern of means in the mortality salience condition reversed this pattern, with more favorable ratings given to the stereotype-consistent target over the stereotype-inconsistent target, but this difference was not significant, $t(73)=1.38, p>.15$. Means and standard deviations are presented in Table 5 .

The findings of Study 4 conceptually replicate those of Study 3 with a different group stereotype. Mortality salience increased the favorability of impressions of the stereotype-consistent target and tended to decrease the favorability ratings of the stereotypeinconsistent target. Whereas Bettencourt et al.'s (1997) finding of more favorable impressions of stereotype-inconsistent men and women was replicated in the social exclusion control condition, the pattern was nonsignificantly reversed in the mortality salience condition. The fact that patterns were essentially the same for male and female targets in Study 4 and African Americans in Study 3 reduces the plausibility of explanations involving factors specific to any particular stereotype.

The fact that mortality salience completely reversed the normal pattern of participants' liking for the stereotype-consistent and stereotype-inconsistent men, women, and African Americans suggests that there are undoubtedly multiple determinants of in-group members' evaluations of out-group members. The finding that participants preferred the stereotype-inconsistent target over the

\footnotetext{
${ }^{7}$ The pictures and the general information in the resumes used in Study 4 were identical to the materials used in Bettencourt et al. (1997, Study 3 ) and were obtained through correspondence with the first author.
} 
stereotype-consistent target in the control conditions in these studies may reflect a general tendency to prefer similar others over dissimilar others (cf. Byrne, 1971; Jussim et al., 1996). Alternatively, as Jussim et al. (1996) argued, it may be that out-group members who violate stereotypes, which are usually negative, are typically preferred because their out-group status is seen as a barrier to such behavior, and this serves to augment (Kelley, 1971) the evaluations such individuals are given. However, when mortality is salient, participants presumably have a greater need for confirmation of their cultural worldviews and thus exhibit a reversal of this preference by increasing their liking for the stereotypeconsistent individual who confirmed their worldviews and decreasing their liking for the stereotype-inconsistent individual who disconfirmed their worldviews. TMT suggests that, although there are many factors that influence reactions to out-group members, it is this need for a stable, consistent worldview that leads to the preference for stereotype-consistent out-group members. Study 5 was designed to provide further evidence concerning the hypothesized role of high need for validation of one's worldview as a moderator of this relationship, by comparing individuals high and low in need for closure (NFC; Kruglanski, Webster, \& Klem, 1993), a variable likely to be associated with high needs for validation of one's cultural worldview.

\section{Study 5}

Study 5 investigated the effect of mortality salience on reactions to stereotype-consistent and stereotype-inconsistent homosexual men. These individuals are generally stereotyped as being artistic, feminine, and emotional (Jackson \& Sullivan, 1990; Kite \& Deaux, 1987; Page \& Yee, 1985). Although these stereotypic traits are not inherently negative, many "straight" individuals hold negative views of stereotype-consistent gay men, perhaps because they differ from the conventional expectations of male behavior or because they threaten the masculine way of life. Conversely, gay men who do not fit the feminine stereotype may appear more similar to the way a typical straight male "should" behave, and this similarity may reduce some of the negativity that straight individuals hold toward gay men. However, to the extent that mortality salience increases people's need for validation of their worldviews, we hypothesized that mortality salience would reverse the usual preference for stereotype-inconsistent gay men such that mortality salient, heterosexual participants would prefer a stereotypeconsistent "feminine" gay man over a stereotype-inconsistent "masculine" one.

To the extent that the preference for stereotype-confirming individuals in response to mortality salience observed in Studies 3 and 4 is moderated by an especially strong need for a stable and consistent cultural worldview, this effect should be especially prominent among those who are dispositionally high in this need. Consistent with this reasoning, Schaller, Boyde, Yohannes, and O'Brien (1995) found that individuals high in personal need for -structure (a personality variable that is conceptually similar to NFC) were more likely than individuals low in personal need for structure to form erroneous negative stereotypes of a disadvantaged group. Similarly, Neuberg and Newsom (1993) found that people high in personal need for structure were more likely to use stereotypes to evaluate others. In a related vein, Kruglanski et al. (1993) found that people high in NFC are more likely to use a prior informational base to form their opinions. Such individuals were shown to refrain from processing further information on a topic for which they already had closure. Thus, Study 5 tested the hypothesis that high NFC individuals would be especially likely to respond to mortality salience with increased liking for stereotypeconsistent members of out-groups. ${ }^{8}$ Support for this hypothesis would provide further evidence for the terror management view that mortality salience increases the need for a stable, consistent conception of social reality and would delineate the types of individuals who are most likely to respond to mortality salience in this manner.

To address these issues, we categorized participants as high or low in NFC using Kruglanski et al.'s (1993) NFC scale. Participants were asked to describe their thoughts and feelings about either death or a neutral topic (i.e., television) and then read a brief self-description of a gay male student. We manipulated whether the description of the gay student was consistent or inconsistent with commonly held stereotypes of gay men (Jackson \& Sullivan, 1990; Kite \& Deaux, 1987; Page \& Yee, 1985). We predicted that high NFC participants would express greater liking for the stereotype-inconsistent target than for the stereotype-consistent target but that this pattern would be reversed for participants in the mortality salient condition. It was less clear what to predict for participants who scored low on NFC. However, we suspected that low NFC participants might be less concerned about verifying their preferred views and more concerned about maintaining a view of themselves as open and accepting of those who are different, something we have found previously in people low in authoritarianism and high in liberal political orientation (cf. Greenberg, Simon, et al., 1992). Thus, there is reason to expect that low NFC participants will not respond to mortality salience with a strong preference for the stereotype-consistent effeminate gay man. In fact, they might even show a reversed preference after mortality salience; if being open to new experience and accepting those who are different or unusual is a way that low NFC individuals maintain their self-conceptions and manage their worldviews, then, for these participants, mortality salience may actually increase liking for the stereotype-inconsistent target over the stereotype-consistent target.

\footnotetext{
${ }^{8}$ Another reason why we examined individual differences in NFC is that a good deal of recent research has demonstrated that although people may hold stereotypes about other groups (e.g., African Americans and homosexual men), they may not outwardly express prejudiced attitudes toward them. For this reason, we believed that NFC would be a better measure of a need for stereotypes than level of prejudice. Furthermore, it is our contention that terror management concerns may lead to stereotyping of minority groups within a culture that does not necessarily entail derogation. We suspected that people high in level of prejudice, for whom a highly negative view of out-groups is an important worldview component, would show strong dislike for all out-group members in our control conditions (regardless of stereotypicality) and an exaggerated dislike under mortality salience. However, our interest here was in the terror management function of stereotypes independent of simple derogation of those who are culturally different. Although this would be an interesting finding, it would not allow us to assess the idea that mortality salience leads to different reactions to stereotype-consistent and stereotype-inconsistent targets that go beyond the simple derogation of out-group members.
} 


\section{Method}

Participants. Eighty-nine students at Pikes Peak Community College in Colorado Springs participated in exchange for partial course credit. Four participants were dropped because they indicated that they were either gay or bisexual, leaving a total of 85 ( 60 female and 25 male) participants. The excluded participants were distributed roughly evenly across conditions.

Procedure. Participants completed the experiment in groups ranging in size from 12 to 25 and were randomly assigned to experimental conditions in a 2 (mortality salience: death vs. television) $\times 2$ (gay target: stereotype consistent vs. stereotype inconsistent) between-groups design. The experimenter introduced the experiment to each group of participants as a two-part study on personality and how people form impressions of others. Participants were told that the first part of the study simply involved filling out a packet of several personality questionnaires. The second part of the study was described as an impression formation task in which participants would read a self-authored description of another student and then rate the personality of this person. The experimenter also mentioned to participants that each of them would receive a different student description and that this description was chosen randomly from a collection of several descriptions written by students in an experiment conducted during the previous semester. The purpose of this pretext was to enhance the perception that the student description was real. The student description comprised a separate packet that was paper-clipped to the first packet. After completing the first packet of questionnaires, participants began the second packet by reading about a person who described himself as a stereotype-consistent or stereotype-inconsistent gay man. After reading about this person, participants were asked to answer some questions about the gay target and rate him on several traits.

The final page in the second packet asked participants to indicate their gender, marital status, sexual orientation, political orientation, and ethnic background. When participants had completed each packet, they were debriefed, given credit, thanked, and dismissed.

Materials. The first packet contained the social desirability scale as a filler (Crowne \& Mariowe, 1960), the NFC scale (Kruglanski et al., 1993), and the same mortality salience manipulation used in the previous studies that asked participants two open-ended questions about either death or television. Because previous studies have shown that mortality salience effects occur when death-related thoughts are on the "fringes of consciousness," highly accessible but not in current focal attention (Arndt, Greenberg, Pyszczynski, \& Solomon, 1997; Greenberg et al., 1994), a short word search puzzle followed the mortality salience manipulation to serve as a distracter task. The previous studies reported in this article used the PANAS questionnaire as a distracter, which was generally followed by an introduction to a second study. However, in Study 5, all of the materials and instructions were given at once and administered to large groups of students in a classroom situation. Thus, we decided to use the word search puzzle because it served as a better separation of the packets that were initially described to the participants as two separate studies. The second packet contained a self-authored description of a student who was always described as a 23-year-old male college sophomore. The remainder of the description constituted the stereotypicality manipulation.

The stereotype-consistent gay person was described as a theater major who likes to "visit art galleries, go.to discos, and go shopping." In a short paragraph about himself, the stereotype-consistent person wrote: "Well, I guess I should start off by telling you that $I$ am gay because that is the biggest part of who I am." The stereotype-consistent person went on to say that he is "neat, well mannered, talkative, and emotional when it comes to relationships." He also mentioned that he liked "going to coffee houses, dancing, and going to plays and musicals."

The stereotype-inconsistent gay person was described as an engineering major who likes to "restore old cars, play basketball, and lift weights." In a paragraph about himself, the stereotype-inconsistent person also said that being gay was the biggest part of who he was. He went on to say that he was "a little messy at times, logical, and not very emotional." The stereotype-inconsistent person then reiterated that he liked working on old cars and playing basketball and added that he also liked going "off-roading."

The dependent measure of liking consisted of the same two questions about liking and wanting to meet the target person used in Study 3 (on 9-point scales). Participants were also asked to rate the target person on the same 12 traits ( 6 positive and 6 negative) used in Study 3 and to rate the target on 20 additional traits ( 10 masculine and 10 feminine) taken from the short form of Bem's (1974) Sex Role Inventory.

\section{Results and Discussion}

Unless otherwise specified, data were analyzed in 2 (mortality salience: death vs. television) $\times 2$ (gay target: stereotype consistent vs. stereotype inconsistent) $\times 2$ (NFC: high vs. low) ANOVAs. There were three primary dependent measures: liking for the target, a composite measure of positive and negative traits attributed to the target, and separate measures of feminine and masculine traits attributed to the target.

Liking for the target. As in Study 3, the two questions that assessed liking and desire to meet the target were combined to form one dependent measure. An ANOVA produced two-way interactions for both mortality salience and stereotypicality of gay target, $F(1,77)=5.22, p<.05$, and NFC and stereotypicality of gay target, $F(1,77)=6.63, p<.05$. These two-way interactions were qualified, however, by the predicted three-way NFC $\times$ Mortality Salience $\times$ Stereotypicality of Gay Target interaction, $F(1,77)=13.62, p<.001$. Cell means for the three-way interaction are presented in Table 6.

Individual 2 (mortality salience: death vs. television) $\times 2$ (gay target: stereotype consistent vs. stereotype inconsistent) ANOVAs (using the error term from the overall analysis) for high and low NFC participants revealed significant effects among high NFC participants but no effects among low NFC participants. The two-way ANOVA for high NFC participants revealed main effects of mortality salience, $F(1,37)=4.29, p<.05$, and stereotypicality of gay target, $F(1,37)=8.68, p<.01$, along with the predicted interaction, $F(1,37)=16.12, p<.001$. Pairwise comparisons between mortality salient and control conditions among high NFC participants revealed that (a) mortality salience led to a significant decrease in liking for the stereotype-inconsistent gay target, $t(37)=8.36, p<.001$, and (b) mortality salience led to a nonsignificant increase in liking for the stereotype-consistent gay target, $t(37)=1.30, p<.20$. Pairwise comparisons within the control conditions revealed a pattern somewhat similar to that found in Study 3, although the difference between means was not significant. Participants tended to like the gay target more when he disconfirmed the stereotype than when he confirmed it, $t(37)=0.81, p>.25$. Pairwise comparisons within the mortality salient conditions revealed an opposite pattern of liking for the stereotype-consistent gay target over the stereotype-inconsistent gay target, $t(37)=5.56, p<.001$. None of the pairwise comparisons for low NFC participants were significant, but the pattern of means tended to be opposite to the pattern of means for high NFC participants (see Table 6).

Positive and negative traits. As in Study 3, the negative traits were reversed scored and summed with the positive traits and then divided by the number of traits to create a favorability composite of trait attributions. An ANOVA revealed a main effect of gay target, $F(1,77)=12.50, p<.001$; a Mortality Salience $\times$ Gay 
Table 6

Cell Means for the Three-Way Need for Closure $\times$ Mortality Salience $\times$ Stereotypicality of Gay Target Interaction on Liking and Desire to Meet the Target in Study 5

\begin{tabular}{|c|c|c|c|c|c|c|c|c|}
\hline \multirow[b]{4}{*}{ Gay target } & \multicolumn{8}{|c|}{ Need for closure } \\
\hline & \multicolumn{4}{|c|}{ High } & \multicolumn{4}{|c|}{ Low } \\
\hline & \multicolumn{2}{|c|}{$\begin{array}{l}\text { Mortality } \\
\text { salient }\end{array}$} & \multicolumn{2}{|c|}{ TV } & \multicolumn{2}{|c|}{$\begin{array}{l}\text { Mortality } \\
\text { salient }\end{array}$} & \multicolumn{2}{|c|}{ TV } \\
\hline & $M$ & $S D$ & $M$ & $S D$ & $M$ & $S D$ & $M$ & $S D$ \\
\hline $\begin{array}{l}\text { Stereotype consistent } \\
\text { Stereotype inconsistent }\end{array}$ & $\begin{array}{l}6.06_{\mathrm{b}} \\
2.00_{\mathrm{a}}\end{array}$ & $\begin{array}{l}1.96 \\
0.93\end{array}$ & $\begin{array}{l}4.92_{\mathrm{b}} \\
5.55_{\mathrm{b}}\end{array}$ & $\begin{array}{l}2.57 \\
.907\end{array}$ & $\begin{array}{l}4.23_{\mathrm{b}} \\
5.08_{\mathrm{b}}\end{array}$ & $\begin{array}{l}2.11 \\
1.718\end{array}$ & $\begin{array}{l}5.00_{\mathrm{b}} \\
4.75_{\mathrm{b}}\end{array}$ & $\begin{array}{l}1.83 \\
1.06\end{array}$ \\
\hline
\end{tabular}

Note. Means that do not share a common subscript differ at $p<.05$. Scores could range from 1 (negative response) to 9 (positive response).

Target interaction, $F(1,77)=4.39, p<.05$; and a Mortality Salience $\times$ NFC interaction, $F(1,77)=6.85, p<.02$. These effects were qualified by the predicted three-way NFC $\times$ Mortality Salience $\times$ Gay Target interaction, $F(1,77)=4.01, p<.05$ (see Table 7 for cell means).

Individual 2 (mortality salience: death vs. television) $\times 2$ (gay target: stereotype consistent vs. stereotype inconsistent) ANOVAs (using the error term from the overall analysis) were conducted separately for high and low NFC participants. The two-way ANOVA for high NFC participants produced main effects of mortality salience, $F(1,37)=5.86, p<.05$, and gay target, $F(1$, $37)=3.97, p<.06$, that were qualified by the predicted Mortality Salience $\times$ Gay Target interaction, $F(1,37)=5.70, p<.05$.

Pairwise comparisons between mortality salience and control conditions of trait attribution means for high NFC participants revealed that mortality salience led to a decrease in favorability ratings of the gay target when he was stereotype inconsistent, $t(37)=3.59, p<.001$, but mortality salience did not produce a difference in favorability ratings for the gay target when he was stereotype consistent $(p>.50)$. Pairwise comparisons within the control conditions revealed that the stereotype-inconsistent gay target was seen more positively than the stereotype-consistent gay target, although this difference was not significant $(p>.25)$. Pairwise comparisons within the mortality salient conditions revealed a pattern opposite to that found in the control conditions:
Participants made significantly more favorable trait ratings of the gay target when he was stereotype consistent than when he was stereotype inconsistent, $t(37)=2.82, p<.005$.

The two-way ANOVA for low NFC participants produced only a main effect of gay target, $F(1,40)=11.23, p<.01$, indicating that the stereotype-consistent gay target was rated more positively than the stereotype-inconsistent gay target. Perhaps this more positive evaluation of the stereotype-consistent gay target reflects a general attempt to be tolerant and open-minded among low NFC individuals.

Feminine and masculine traits. The gender-typed traits were summed and divided by the number of traits to form separate composite measures of feminine and masculine trait ascriptions. An ANOVA produced a main effect of stereotypicality of target, $F(1,77)=77.96, p<.001$, and a three-way interaction, $F(1$, 77) $=5.90, p<.05$.

Separate 2 (mortality salience: death vs. television) $\times 2$ (gay target: stereotype consistent vs. stereotype inconsistent) ANOVAs (using the error term from the overall analysis) were performed for high NFC and low NFC participants. The two-way ANOVA for high NFC participants revealed a main effect of stereotypicality of target, $F(1,37)=32.74, p<.001$, that was qualified by a Mortality Salience $\times$ Stereotypicality interaction, $F(1,37)=4.38$, $p<.05$. Pairwise comparisons between mortality salience and control conditions indicated that mortality salience led to margin-

Table 7

Cell Means for the Three-Way Need for Closure $\times$ Mortality Salience $\times$ Stereotypicality of Gay Target Interaction on Trait Ratings of Favorability in Study 5

\begin{tabular}{|c|c|c|c|c|c|c|c|c|}
\hline & \multicolumn{8}{|c|}{ Need for closure } \\
\hline & \multicolumn{4}{|c|}{ High } & \multicolumn{4}{|c|}{ Low } \\
\hline & \multicolumn{2}{|c|}{$\begin{array}{l}\text { Mortality } \\
\text { salient }\end{array}$} & \multicolumn{2}{|c|}{ TV } & \multicolumn{2}{|c|}{$\begin{array}{l}\text { Mortality } \\
\text { salient }\end{array}$} & \multicolumn{2}{|c|}{ TV } \\
\hline Gay target & $M$ & $S D$ & $M$ & $S D$ & $M$ & $S D$ & $M$ & $S D$ \\
\hline $\begin{array}{l}\text { Stereotype consistent } \\
\text { Stereotype inconsistent }\end{array}$ & $\begin{array}{l}5.28 \mathrm{a} \\
3.94_{\mathrm{b}}\end{array}$ & $\begin{array}{l}0.93 \\
1.02\end{array}$ & $\begin{array}{l}5.29 \mathrm{a} \\
5.41_{\mathrm{a}}\end{array}$ & $\begin{array}{l}1.16 \\
0.64\end{array}$ & $\begin{array}{l}5.58 \mathrm{a} \\
4.92 \mathrm{a}\end{array}$ & $\begin{array}{l}0.36 \\
0.74\end{array}$ & $\begin{array}{l}5.38 \\
4.74_{\mathrm{a}}\end{array}$ & $\begin{array}{l}0.56 \\
0.80\end{array}$ \\
\hline
\end{tabular}

Note. Means that do not share a common subscript differ at $p<.05$. Scores could range from 1 (negative response) to 7 (positive response). 
Table 8

Cell Means for the Three-Way Need for Closure $\times$ Mortality Salience $\times$ Stereotypicality of Gay Target Interaction on Attributions of Femininity in Study 5

\begin{tabular}{|c|c|c|c|c|c|c|c|c|}
\hline \multirow[b]{4}{*}{ Gay target } & \multicolumn{8}{|c|}{ Need for closure } \\
\hline & \multicolumn{4}{|c|}{ High } & \multicolumn{4}{|c|}{ Low } \\
\hline & \multicolumn{2}{|c|}{$\begin{array}{c}\text { Mortality } \\
\text { salient }\end{array}$} & \multicolumn{2}{|c|}{ TV } & \multicolumn{2}{|c|}{$\begin{array}{c}\text { Mortality } \\
\text { salient }\end{array}$} & \multicolumn{2}{|c|}{ TV } \\
\hline & $M$ & $S D$ & $M$ & $S D$ & $M$ & $S D$ & $M$ & $S D$ \\
\hline Stereotype consistent & $5.13_{\mathrm{a}}$ & 0.50 & $4.46_{b}$ & 1.13 & $4.62_{\mathrm{a}, \mathrm{b}}$ & 0.72 & $4.97_{\mathrm{a}, \mathrm{b}}$ & 0.44 \\
\hline Stereotype inconsistent & $3.06_{c}^{4}$ & 0.55 & $3.50_{\mathrm{c}}$ & 0.79 & $3.28_{c}$ & 1.04 & $2.99_{\mathrm{c}}$ & 0.81 \\
\hline
\end{tabular}

Note. Means that do not share a common subscript differ at $p<.06$. Scores could range from 1 (not at all feminine) to 7 (very feminine).

ally higher feminine ratings of the stereotype-consistent gay target, $t(37)=1.89, p<.06$. In both the mortality salient and control conditions, participants made higher feminine ratings for the stereotype-consistent gay target than for the stereotypeinconsistent gay target, $t(37)=7.20, p<.001$, and $t(37)=2.86$, $p<.01$, respectively. Cell means for composite femininity ratings are presented in Table 8 .

The two-way ANOVA for low NFC participants revealed only a main effect of gay target, $F(1,40)=46.26, p<.001$, such that the stereotype-consistent target was seen as more feminine than the stereotype-inconsistent target. A composite measure of masculine trait ascriptions was also constructed by summing the masculine traits and dividing by the number of traits. On the composite masculine trait ascriptions, only a main effect of stereotypicality of gay target was revealed by the three-way ANOVA, $F(1$, 77) $=40.52, p<.001$, indicating significantly higher masculine ratings for the stereotype-inconsistent target than for the stereotype-consistent target.

In sum, Study 5 conceptually replicated the effects of Studies 3 and 4 , but only among participants high in NFC. Although high NFC participants in the control condition tended to prefer a stereotype-inconsistent masculine gay man over a stereotypeconsistent feminine gay man, mortality salience reversed this preference and led to a significant decrease in liking for and favorability of trait ratings of a stereotype-inconsistent gay man. As in Studies 3 and 4 , mortality salience pushed participants toward preferring a stereotype-confirming out-group member over a stereotype-disconfirming one. And, as might be expected if this effect reflects a need for faith in one's worldview, the effect emerged only among participants dispositionally high in NFC.

These findings extend the generality of the findings of Studies 3 and 4 to another out-group and, by so doing, greatly reduce the plausibility of several alternative explanations for the effect of mortality salience on reactions to stereotype-consistent and stereotype-inconsistent out-group members. Whereas it might be argued that the stereotype-inconsistent Black confederate in Study 3 and perhaps even the male and female targets in Study 4 were perceived as rather "nerdish," this seems highly unlikely for the masculine gay man in Study 5. Similarly, although it might be argued that the increased liking for a stereotype-consistent Black male target in Study 3 resulted from mortality salience increasing participants' need to be "politically correct," this seems unlikely as an explanation for the decreased liking of the stereotypeinconsistent male and female job applicants in Study 4 and the stereotype-inconsistent gay man in Study 5. Most important, whereas the "nerd negativity" and "political correctness" alternatives might each be able to account for some specific differences between conditions in Studies 3 and 4 , neither is able to account for the entire pattern of data across the three studies. The TMT proposition that stereotypes, as an element of the cultural worldview, provide protection against deeply rooted fears of vulnerability and mortality can parsimoniously account for the findings of all five of the present studies.

The fact that, in Study 5, mortality salience produced a preference for stereotype-confirming out-group members only among participants high in NFC (Kruglanski et al., 1993) adds further credence to the terror management view that, by providing a sense of stability in a frightening and confusing social world, stereotypes provide protection against death-related fear. To the extent that mortality salience intensifies participants' need to uphold their stereotype-consistent conceptions of out-groups, it follows that this tendency would be strongest among individuals who are generally high in NFC. Of course, in Studies 3 and 4, mortality salience increased preference for the stereotype-consistent target across all participants, whereas in Study 5, this effect emerged only among the high NFC participants. It may be that the effects in Studies 3 and 4 were driven by participants high in NFC; because we did not measure this construct in those studies, however, we can only speculate about this possibility. Another possibility is that racial and gender stereotypes are particularly ingrained components of the worldview conveyed by American culture, and consequently, after mortality salience, preference for stereotypes is not limited to individuals high in NFC. It is also possible that differences among the dynamics of racism, sexism, and homophobia, and perhaps in the way they are manifested in University of Arizona and Pikes Peak Community Coliege students, account for the more general effects found in Studies 3 and 4 than in Study 5.

\section{General Discussion}

Across five studies examining stereotypes based on nationality, race, gender, and sexual orientation, it was shown that mortality salience increased the use of stereotypes when participants were thinking about members of various social groups. Study 1 dem- 
onstrated that mortality salience increased the ascription of stereotype-consistent traits to Germans, a group that our American college students did not particularly dislike. Study 2 demonstrated that mortality salience increased participants' desire to explain behavior that deviated from sex role stereotypes. To the extent that unexpected stereotype-inconsistent behavior is especially likely to instigate such causal processing (cf. Pyszczynski \& Greenberg, 1981; von Hippel et al., 1997), these findings suggest that mortality salience increased the use of stereotypes and thus conceptually replicate the findings of Study 1. Study 3 demonstrated that mortality salience increased preference for a stereotype-confirming African American student over a stereotype-disconfirming African American, and Study 4 demonstrated a similar effect on evaluations of male and female job applicants. Study 5 demonstrated that, among high NFC participants, mortality salience increased preference for a stereotype-confirming feminine gay man over a stereotype-disconfirming masculine gay man. Thus, across four distinct social groups, mortality salience increased the influence of group stereotypes on participants' trait ascriptions and evaluations of individual members of those groups.

From the perspective of TMT, this increased commitment to social stereotypes in response to reminders of one's mortality reflects the terror management function that such stereotypes serve. By simplifying social reality and rendering the behavior of out-group members more predictable and easily interpreted, social stereotypes are part of the orderly, meaningful conception of reality necessary to protect people from deeply rooted existential fear. By viewing out-groups stereotypically (as shown in Studies 1 and 2) and increasing preference for stereotype-consistent over stereotype-inconsistent out-group members (as shown in Studies 3, 4 , and 5), the individual affirms the validity of his or her conception of the social world. The fact that mortality salience was shown to increase these tendencies across all five studies suggests that the tendency to apply stereotypes is increased by contemplation of death.

How does seeing Germans as goose-stepping authoritarian marionettes, women and men as Barbies and Kens, African Americans as gangsta rappers, or gay men as effeminate wimps provide protection against the fear of death? Building on prior analyses by Rank (1936), Becker (1973), Berger and Luckmann (1967), and others, TMT suggests that the human need for meaning is strongly influenced by awareness of the futility of a very basic human motive, that of simply staying alive. Because of the potential for terror that awareness of the inevitability of death creates, individuals are driven to see themselves as objects of primary value living in a world of absolute meaning. Human conceptions of individuals and groups are part of the meaningful universe in which individuals strive to establish their value and thus transcend the fear of death. By seeing others as instances of social stereotypes and preferring others who confirm stereotypes over those who disconfirm them, individuals reify their conception of social reality and thus increase its effectiveness as a shield against deeply rooted fears.

We have recently argued (Greenberg et al., 1997; Pyszczynski, Greenberg, \& Solomon, 1999) that self-esteem and faith in the cultural worldview function to provide protection against existential fears because of early experiential linkages between parental love and acceptance of parents' teachings about the nature of reality, on the one hand, and the quelling of primitive fears that are triggered by a lack of need fulfillment or other events that threaten people's continued existence, on the other. Thus, terror management defenses are not rational. They do not stand up to logical scrutiny by the individual who is using them, and when they are subjected to such scrutiny, they are not likely to be used. Consequently, people use different defenses to deal with the problem of death in and outside of consciousness. Whereas relatively rational defenses that directly address the problem of death are used when death-related thoughts are conscious or in current focal attention (e.g., "I'm young and healthy, get lots of exercise, don't smoke, and avoid saturated fat; what have I got to worry about?"), an entirely different set of symbolic defenses that embed the individual as an object of primary value in a world of meaning (i.e., self-esteem and faith in the cultural worldview) is used when death-related thought becomes preconscious (i.e., when such thoughts are highly accessible but not in current focal attention). Recent evidence in support of this analysis includes findings that (a) subtle reminders of one's mortality produce larger effects on symbolic worldview defense than more blatant ones (Greenberg et al., 1994, Study 1), (b) mortality salience increases symbolic worldview defense when participants are distracted from the problem of death but not when they are forced to dwell on it (Greenberg et al., 1994, Studies 2 and 3), (c) subliminal exposure to death-related stimuli produces immediate symbolic worldview defense with no need for distraction (Amdt et al., 1997), (d) symbolic. worldview defense increases in response to reminders of one's mortality when one is in an experiential but not when one is in a rational mode of information processing (Simon, Greenberg, Harmon-Jones, et al., 1997), and (e) although symbolic worldview defense emerges in response to mortality salience only after a delay and distraction, rational threat-focused defense emerges immediately after mortality salience but not after a distraction (Greenberg, Arndt, Simon, Pyszczynski, \& Solomon, in press).

Thus, although viewing out-group members in a stereotypic manner in no way changes the fact that death is inevitable and does not even relate to this ultimate reality in a logical or semantic way, such conceptions are part of the meaning-providing conception of reality that enables people to live out their daily lives with minimal confrontation with the ultimate inevitability of death. The facts that mortality salience increases the tendencies to use such stereotypes and increases one's preferences for individuals who fit neatly into one's social categories suggest that, by seeing individuals as exemplars of broader social categories, one reaffirms the correctness of these categories, thus increasing the power of one's conception of reality to protect one from one's most profound fears.

\section{A Terror Management Perspective on Individual Differences}

TMT is a broad theory of human behavior. It seeks to explain a wide range of superficially unrelated behaviors and motives as ultimately rooted in the existential dilemma into which humans are born (for a discussion of the role of terror management concerns in various specific social motives, see Pyszczynski, Greenberg, \& Solomon, 1997). It assumes that the fear of death and the pursuit of meaning and value as means of battling this fear are universal. At least in Study 5, however, only those individuals high in NFC responded to mortality salience with an increased preference for stereotype-consistent over stereotype-inconsistent members of out- 
groups. How does this finding of individual differences in response to mortality salience square with the assumption of a universal pursuit of meaning and value to cope with an equally universal fear of death?

Although TMT assumes that the need for meaning and value is part of the universal design of the human animal, this in no way implies that all people at all times and in all situations pursue meaning and value in the same way. From the perspective of TMT, each person acquires an individualized version of the cultural worldview and pursues a unique set of standards of personal value that are creatively abstracted from the broad range of socializing experiences to which he or she is exposed (for a more thorough discussion of this individualized process of self-creation, and the role that anxiety plays in limiting the flexibility of this selfcreation, see Pyszczynski, Greenberg, \& Solomon, 1998). Thus, although all humans fear death and fight to quell this fear by the pursuit of meaning and value, people vary widely in the conceptions of reality through which they seek meaning and the standards of value through which they pursue self-esteem.

Within the context of Study 5, individual differences in NFC were shown to predict who would react most strongly to mortality salience with increased preference for stereotype-confirming outgroup members. We suggest that although all people need a stable, coherent conception of reality (in Kruglanski et al.'s, 1993, terms, an NFC), people and cultures vary widely in the strength of this motive and in their tolerance for ambiguity, uncertainty, and inconsistency (cf. Schaller et al., 1995; Wicklund, 1997). The more one uses consistency and structure as a means of combating one's fears, the more one is likely to increase one's pursuit of these psychological entities when one is reminded of the source of one's fears. Just as previous terror management research has shown that responses to mortality salience are affected by individual differences in political orientation (Greenberg, Simon, et al., 1992), authoritarianism (Greenberg et al., 1990), self-esteem (Greenberg et al., 1993; Harmon-Jones et al., 1997), and depression (Simon, Arndt, Greenberg, Pyszczynski, \& Solomon, 1998), Study 5 demonstrates that NFC increases the likelihood that people will respond to reminders of their mortality with increased need for confirmation of their stereotyped conceptions of members of various social categories. These results suggest that further inquiry into the role of individual differences in responses to reminders of one's mortality may be fruitful.

\section{Prejudice Against the Dissimilar and Against the Stereotype Inconsistent}

Our findings also present a new complexity to the long-standing issue of whether prejudice against minority groups is produced by their ethnic identity per se or by assumptions of differences in beliefs, values, and lifestyles that are inferred from ethnic differences. In support of this latter view, TMT and terror management research clearly indicate that those who implicitly or explicitly espouse views very different from one's own will be reacted to negatively, especially after mortality salience (see, e.g., Greenberg et al, 1997). This is, of course, broadly consistent with other analysis and research (e.g., Allport, 1954; Jussim et al., 1996; Rokeach, 1960), as well as with the present control condition findings: In the absence of mortality salience, majority group members generally preferred stereotype-inconsistent members of out-groups who were presumably perceived as more similar to themselves.

However, when reminded of their own mortality, participants showed a consistent preference for stereotype-consistent members of the out-groups, even though these individuals were presumably perceived as dissimilar to themselves. This indicates that when out-group members are also an established and stereotyped part of an in-group member's culture, the threat, after mortality salience (when in-group members' need to bolster faith in their worldview is high), of out-group members disconfirming the stereotype is greater than the threat of such out-group members being different from in-group members. Perhaps this is because, as stereotyped out-group members, they are not used by in-group members primarily to validate in-group beliefs and values in general; rather, they are used to validate in-group categorizations, stereotypes, and feelings of superiority. Consequently, when worldview bolstering is needed, the in-group member may actually display more prejudice against the relatively similar but stereotype-inconsistent outgroup member than against the more dissimilar but stereotypeconsistent out-group member.

\section{Summary and Conclusions}

These studies considerably extend previous research on the role of death-related fear in the genesis and maintenance of prejudice and in-group bias. Whereas previous studies have shown that mortality salience increases in-group bias, rejection of out-group members, and negative evaluations of those who are different (e.g., Greenberg et al., 1990; Harmon-Jones et al., 1996; Ochsmann \& Mathy, 1994), the current research shows that mortality salience also increases people's tendencies to perceive out-group members in stereotype-consistent ways and to prefer out-group members who conform to these stereotypes over those who do not. The present findings demonstrate that, beyond simply providing a convenient context for derogating those who are different, information consistent with cultural stereotypes also serves the important function of bolstering faith in one's view of social reality.

The present analysis suggests that the motivational and cognitive perspectives on prejudice and intergroup conflict, which have often been seen as mutually exclusive ways of understanding this serious human social problem, may, in fact, be quite compatible. Whereas motivational theorists have typically emphasized the role of fear and insecurity in the derogation of those who are different to enhance one's sense of the value of oneself and one's group, cognitive theorists have typically emphasized the role of preexisting cognitive structures, cognitive laziness, and an NFC as lying at the root of intergroup conflict. From the perspective of TMT, people are motivated to understand the social world and see themselves as objects of primary value within that world because doing so provides protection against the fears inherent in being an animal with an instinctive desire for life that knows it must die. Stereotypes function, in part, to buttress a meaningful, albeit highly oversimplified, conceptualization of reality, and by so doing they contribute to the psychological structures necessary to function in today's frightening world with a modicum of equanimity.

Although, under some circumstances, minority stereotypes serve the psychological needs of the majority, we in no way mean to imply that they are constructs to be valued. The fact that, when 
faced with reminders of their mortality, people actually prefer minority group members to conform to narrow, often negatively viewed stereotypes suggests a difficult problem for minority group members interested in succeeding in society outside the narrow. bounds of stereotypically prescribed roles such as the athlete for Blacks and the hair stylist for gay men. This predicament is not lost on members of minority groups. For example, consider the following drunken diatribe by a downtrodden Black father, played by George T. Odon, in Matty Rich's 1991 film Straight Out of Brooklyn:

You had my father telling me I could be anything I wanted to be. Yeah a goddamn lawyer. Yeah a doctor; you'd even tell him I could be president. I believed that shit. I believed that shit. You don't want me to eat with you. You don't want me to provide for my family. You don't want me to think; you don't want me to be a goddamn man. Because you afraid of me. You afraid that I'm going to take your woman. You afraid I'm going to take your house. You afraid I'm going to start to think just like you.

White American culture espouses assimilation in many ways. However, when White Americans sorely need the security base of the status quo worldview, could it be that minorities are desired not across the full domain of roles in society but, rather, only in the restricted roles that do not call into question the meaning system by which the majority derives its equanimity? Sadly, the present research suggests that the answer is yes.

\section{References}

Allport, G. W. (1954). The nature of prejudice. Reading, MA: AddisonWesley.

Arndt, J., Greenberg, J., Pyszczynski, T., \& Solomon, S. (1997). Subliminal exposure to death-related stimuli increases defense of the cultural worldview. Psychological Science, 8, 379-385.

Arndt, J., Greenberg, J., Simon, L., Pyszczynski, T., \& Solomon, S. (1998). Evidence that mortality salience provokes avoidance of the self-focus state. Personality and Social Psychology Bulletin, 24, 1216-1227.

Baumeister, R. F., \& Tice, D. M. (1990). Anxiety and social exclusion. Journal of Social and Clinical Psychology, 9, 165-195.

Becker, E. (1973). The denial of death. New York: Free Press.

Bem, S. L. (1974). The measurement of psychological androgyny. Journal of Consulting and Clinical Psychology, 42, 155-162.

Berger, P. L., \& Luckmann, T. (1967). The social construction of reality: A treatise in the sociology of knowledge. Garden City, NY: Anchor Books.

Bettencourt, B. A., Dill, K. E., Greathouse, S. A., Charlton, K., \& Mulholland, A. (1997). Evaluations of ingroup and outgroup members: The role of category-based expectancy violation. Joumal of Experimental Social Psychology, 33, 244-275.

Biernat, M. (1991). Gender stereotypes and the relationship between masculinity and femininity: A developmental analysis. Journal of Personality and Social Psychology, 61, 351-365.

Billing, M., \& Tajfel, H. (1973). Social categorization and similarity in intergroup behavior. European Journal of Social Psychology, 3, 27-52.

Brigham, J. C. (1971). Ethnic stereotypes. Psychological Bulletin, 76, 15-38.

Burgess, D., \& Borgida, E. (in press). Who women are, who women should be: Descriptive and prescriptive gender stereotyping in sex discrimination. Psychology, Public Policy, and Law.

Byme, D. (1971). The attraction paradigm. New York: Academic Press. Crowne, D., \& Marlowe, D. (1960). A new scale of social desirability independent of psychopathology. Journal of Consulting Psychology, 24, 349-354.

Devine, G. (1989). Stereotypes and prejudice: Their automatic and controlled components. Journal of Personality and Social Psychology, 56, 5-18.

Devine, G., \& Baker, S. M. (1991). Measurement of racial stereotype sub-typing. Personality and Social Psychology Bulletin, 17, 44-50.

Devine, G., \& Elliot, A. J. (1995). Are racial stereotypes really fading? The Princeton trilogy revisited. Personality and Social Psychology Bulletin, 21, 1139-1150.

Diehl, M., \& Jonas, K. (1991). Measures of national stereotypes as predictors of the latencies of inductive versus deductive stereotypic judgments. European Journal of Social Psychology, 21, 317-330.

Dovidio, J. F., \& Gaertner, S. L. (1998). On the nature of contemporary prejudice: The causes, consequences, and challenges of aversive racism. In J L. Eberhardt \& S. T. Fiske (Eds.), Confronting racism: The problem and the response (pp. 3-32). Thousand Oaks, CA: Sage.

Eagly, A. H. (1987). Are stereotypes of nationalities applied to both women and men? Journal of Personality and Social Psychology, 46, 991-1004.

Eagly, A. H., \& Mladinic, A. (1989). Gender stereotypes and attitudes toward women and men. Personality and Social Psychology Bulletin, 15, 543-558.

Fein, S., \& Spencer, S. J. (1997). Prejudice as self-image maintenance: Affirming the self through derogating others. Journal of Personality and Social Psychology, 73, 31-44.

Festinger, L. (1954). A theory of social comparison processes. Human Relationships, 7, 117-140.

Fishman, J. A. (1956). An examination of the process and function of social stereotyping. Joumal of Social Psychology, 43, 27-64.

Ford, T. E., \& Stangor, C. (1992). The role of diagnosticity in stereotype formation: Perceiving group means and variances. Journal of Personality and Social Psychology, 63, 356-367.

Greenberg, J., Arndt, J., Simon, L., Pyszczynski, T., \& Solomon, S. (in press). Proximal and distal defenses in response to reminders of one's mortality: Evidence of a temporal sequence. Personality and Social Psychology Bulletin.

Greenberg, J., Pyszczynski, T., \& Solomon, S. (1986). The causes and consequences of the need for self-esteem: A terror management theory. In R. F. Baumeister (Ed.), Public self and private self (pp. 189-212). New York: Springer-Verlag.

Greenberg, J., Pyszczynski, T., Solomon, S., Pinel, E., Simon, L., \& Jordan, K. (1993). Effects of self-esteem on vulnerability-denying defensive distortions: Further evidence of an anxiety-buffering function of self-esteem. Journal of Experimental Social Psychology, 29, 229-251.

Greenberg, J., Pyszczynski, T., Solomon, S., Rosenblatt, A., Veeder, M., Kirkland, S., \& Lyon, D. (1990). Evidence for terror management theory: II. The effects of mortality salience reactions to those who threaten or bolster the cultural worldview. Journal of Personality and Social Psychology, 58, 308-318.

Greenberg, J., Pyszczynski, T., Solomon, S., Simon, L., \& Breus, M. (1994). The role of consciousness and accessibility of death-related thoughts in mortality salience effects. Joumal of Personality and Social Psychology, 67, 627-637.

Greenberg, J., Simon, L., Harmon-Jones, E., Solomon, S., Pyszczynski, T., \& Lyon, D. (1995). Testing alternative explanations for mortality salience effects: Terror management, value accessibility, or worrisome thoughts? European Journal of Social Psychology, 25, 417-433.

Greenberg, J., Simon, L., Porteus, J., Pyszczynski, T., \& Solomon, S. (1995). Evidence of a terror management function of cultural icons: The effects of mortality salience on the inappropriate use of cherished cultural symbols. Personality and Social Psychology Bulletin, 21, 12211228.

Greenberg, J., Simon, L., Pyszczynski, T., Solomon, S., \& Chatel, D. 
(1992). Terror management and tolerance: Does mortality salience always intensify negative reactions to others who threaten one's worldview? Journal of Personality and Social Psychology, 63, 212-220.

Greenberg, J., Solomon, S., \& Pyszczynski, T. (1997). Terror management theory of self-esteem and cultural worldviews: Empirical assessments and conceptual refinements. In M. P. Zanna (Ed.), Advances in experimental social psychology (Vol. 29, pp. 61-141). San Diego, CA: Academic Press.

Greenberg, J., Solomon, S., Pyszczynski, T., Rosenblatt, A., Burling, J., Lyon, D., \& Simon, L. (1992). Assessing the terror management analysis of self-esteem: Converging evidence of an anxiety-buffering function. Journal of Personality and Social Psychology, 63, 913-922.

Hamiton, D. D., \& Rose, T. L. (1980). Illusory correlation and the maintenance of stereotypic beliefs. Journal of Personality and Social Psychology, 39, 832-845.

Harding, J., Proshansky, H., Kutner, B., \& Chein, I. (1969). Prejudice and ethnic relations. In G. Lindzey (Ed.), Handbook of social psychology (Vol. 5, pp. 1-76). Reading, MA: Addison-Wesley.

Harmon-Jones, E., Greenberg, J., Solomon, S., \& Simon, L. (1996). The effects of mortality salience on inter-group discrimination between minimal groups. European Journal of Social Psychology, 26, 677-681.

Harmon-Jones, E., Simon, L., Greenberg, J., Pyszczynski, T., Solomon, S., \& McGregor, H. (1997). Terror management theory and self-esteem: Evidence that increased self-esteem reduces mortality salience effects. Journal of Personality and Social Psychology, 72, 24-36.

Hass, G. R., Katz, I., Rizzo, N., Bailey, J., \& Eisenstadt, D. (1991). Cross-racial appraisal as related to attitude ambivalence and cognitive complexity. Personality and Social Psychology Bulletin, 17, 83-92.

Hastie, R. (1984). Causes and effects of causal attribution. Journal of Personality and Social Psychology, 46, 44-56.

Jackson, L. A., \& Sullivan, L. A. (1990). Cognition and affect in evaluations of stereotyped group members. Journal of Social Psychology, 129, 659-672.

Jackson, L. A., Sullivan, L. A., \& Hodge, C. N. (1993). Stereotype effects on attributions, predictions, and evaluations: No two social judgements are quite alike. Journal of Personality and Social Psychology, 65, $69-84$.

Jost, J. T., \& Banaji, M. R. (1994). The role of stereotyping in systemjustification and the production of false consciousness. British Journal of Social Psychology, 33, 1-27.

Jussim, L., Coleman, L. M., \& Lerch, L. (1987). The nature of stereotypes: A comparison and integration of three theories. Journal of Personality and Social Psychology, 52, 536-546.

Jussim, L., Fleming, C. J., Coleman, L. M., \& Kohberger, C. (1996). The nature of stereotypes II: A multiple-process model of evaluations. Journal of Applied Social Psychology, 26, 283-312.

Katz, I. (1981). Stigma: A social psychological analysis. Hillsdale, NJ: Erlbaum.

Katz, I., \& Hass, R. G. (1988). Racial ambivalence and American value conflict: Correlational and priming studies of dual cognitive structures. Journal of Personality and Social Psychology, 55, 893-905.

Kelley, H. H. (1971). Attribution in social interaction. In E. E. Jones, D. Kanouse, H. H. Kelley, R. Nisbett, S. Valins, \& B. Weiner (Eds.), Attribution: Perceiving the causes of behavior (pp. 1-26). Morristown, NJ: General Learning Press.

Kite, M. S., \& Deaux, K. (1987). Gender belief systems: Homosexuality and the implicit inversion theory. Psychology of Women Quarterly, 11, 83-96.

Kruglanski, A. W., Webster, D. M., \& Klem, A. (1993). Motivated resistance and openness to persuasion in the presence or absence of prior information. Joumal of Personality and Social Psychology, 65, 861876.

Kunzendorf, R., Hersey, T., Wilson, J., \& Ethier, M. (1992). Repressed self-consciousness of death and insensitivity to religious genocide. Unpublished manuscript, University of Lowell, Lowell, MA.

Leary, M. R., Tambor, E. S., Terdal, S. K., \& Downs, D. L. (1995). Self-esteem as an interpersonal monitor: The sociometer hypothesis. Journal of Personality and Social Psychology, 68, 518-530.

Locksley, A., Borgida, E., Brekke, N., \& Hepburn, C. (1980). Sex stereotypes and social judgement. Journal of Personality and Social Psychology, 39, 821-831.

Macrae, N., Stangor, C., \& Hewstone, M. (1996). Stereotypes and stereotyping. New York: Guilford Press.

McCauley, C., \& Stitt, C. L. (1978). An individual and quantitative measure of stereotypes. Journal of Personality and Social Psychology, 36, 929-940.

McCauley, C., Stitt, C. L., \& Segal, M. (1980). Stereotyping from prejudice to prediction. Psychological Bulletin, 87, 195-208.

Monteith, M. (1993). Self-regulation of prejudiced responses: Implications for progress in prejudice-reduction efforts. Journal of Personality and Social Psychology, 65, 469-485.

Myrdal, G. (1944). An American dilemma: The Negro problem and modern democracy. New York: Harper.

Neuberg, S. L., \& Newsom, J. T. (1993). Personal need for structure: Individual differences in the desire for simpler structure. Journal of Personality and Social Psychology, 65, 113-131.

Oakes, P. J., \& Turner, J. C. (1980). Social categorization and intergroup behavior: Does minimal intergroup discrimination make social identity more positive? European Journal of Social Psychology, 10, 295-301.

Oakes, P. J., \& Turner, J. C. (1990). Is limited information processing capacity the cause of social stereotyping? In W. Stroebe \& M. Hewstone (Eds.), European review of social psychology (Vol. 1, pp. 111-135). Chichester, England: Wiley.

Ochsmann, R., \& Mathy, M. (1994). Depreciating of and distancing from foreigners: Effects of mortality salience. Unpublished manuscript, Universität Mainz, Mainz, Germany.

Page, S., \& Yee, M. (1985). Conception of male and female homosexual stereotypes among university undergraduates. Journal of Homosexuality, 12, 109-117.

Pyszczynski, T. A., \& Greenberg, J. (1981). Role of disconfirmed expectancies in the instigation of attributional processing. Journal of Personality and Social Psychology, 40, 31-38.

Pyszczynski, T., Greenberg, J., \& Solomon, S. (1997). Why do we need what we need? A terror management perspective on the roots of human motivation. Psychological Inquiry, 8, 1-20.

Pyszczynski, T., Greenberg, J., \& Solomon, S. (1998). Controlling the uncontrollable: A terror management perspective on the psychology of control. In M. Kofta, G. Weary, \& G. Sedek (Eds.), Personal control in action: Cognitive and motivational mechanisms (pp. 85-108). New York: Plenum.

Pyszczynski, T., Greenberg, J., \& Solomon, S. (1999). A dual-process model of defense against conscious and unconscious death-related thoughts: An extension of terror management theory. Psychological Review, 106, 835-845.

Pyszczynski, T., Wicklund, R. A., Floresku, S., Koch, H., Gauch, G., Solomon, S., \& Greenberg, J. (1996). Whistling in the dark: Exaggerated consensus estimates in response to incidental reminders of mortality. Psychological Science, 7, 332-336.

Rank, O. (1936). Truth and reality. New York: Norton.

Rich, M. (1991). Straight out of Brooklyn [Film]. (Available from Samuel Goldwyn Company and Distributed by HBO, 1100 Avenue of the Americas, New York, NY 10036).

Rokeach, M. (1960). The open and closed mind. New York: Basic Books.

Rokeach, M., \& Mezei, L. (1966). Race and shared belief as factors in social choice. Science, 151, 167-172.

Rosenblatt, A., Greenberg, J., Solomon, S., Pyszczynski, T., \& Lyon, D. (1989). Evidence for terror management theory I: The effects of mor- 
tality salience on reactions to those who violate or uphold cultural values. Journal of Personality and Social Psychology, 57, 681-690.

Rosenfield, D., Greenberg, J., Folger, R., \& Borys, R. (1982). Effect of an encounter with a Black panhandler on subsequent helping for Blacks: Tokenism or confirming a negative stereotype? Personality and Social Psychology Bulletin, 8, 664-678.

Ryan, W. (1971). Blaming the victim. New York: Random House.

Schaller, M. (1992). Sample size, aggregation, and statistical reasoning in social inference. Journal of Experimental Social Psychology, 28, 65-85.

Schaller, M. (1994). The role of statistical reasoning in the formation, preservation, and prevention of group stereotypes. British Journal of Social Psychology, 33, 47-61.

Schaller, M., Boyde, C., Yohannes, J., \& O'Brien, M. (1995). The prejudiced personality revisited: Personal need for structure and formation of erroneous group stereotypes. Journal of Personality and Social Psychology, 68, 544-555.

Schaller, M., \& O'Brien, M. (1992). Intuitive analysis of covariance and group stereotype formation. Personality and Social Psychology Bulletin, $18,776-785$.

Sears, D. O., \& McConahay, J. B. (1973). The politics of violence: The new urban Blacks and the Watts riots. Boston: Houghton Mifflin.

Simon, L., Arndt, J., Greenberg, J., Pyszczynski, T., \& Solomon, S. (1998). Terror management and meaning: Evidence that the opportunity to defend the worldview in response to mortality salience increases the meaningfulness of life in the mildly depressed. Journal of Personality, 66, 359-382.

Simon, L., Greenberg, J., Arndt, J., Pyszczynski, T., Clement, R., \& Solomon, S. (1997). Perceived consensus, uniqueness and terror management: Compensatory responses to threats to inclusion and distinctiveness following mortality salience. Personality and Social Psychology Bulletin, 23, 1055-1065.

Simon, L., Greenberg, J., Harmon-Jones, E., Solomon, S., Pyszczynski, T., Andt, J., \& Abend, T. (1997). Terror management and cognitiveexperiential self-theory: Evidence that terror management occurs in the experiential system. Journal of Personality and Social Psychology, 72, $1132-1146$.

Six, B., \& Eckes, T. (1991). A closer look at the complex structure of gender stereotypes. Sex Roles, 24, 57-71.

Snyder, M., \& Miene, P. (1994). On the function of stereotypes and prejüdice. In M. P. Zanna \& J. M. Olson (Eds.), The psychology of prejudice (Vol. 7, pp. 33-54). Hillsdale, NJ: Erlbaum.

Solomon, S., Greenberg, J., \& Pyszczynski, T. (1991). A terror management theory of social behavior: The psychological functions of selfesteem and cultural worldviews. In M. P. Zanna (Ed.), Advances in experimental social psychology (pp. 91-159). San Diego, CA: Academic Press.

Spence, J. T., \& Helmreich, R. L. (1978). Masculinity and femininity: Their psychological dimensions, correlates, and antecedents. Austin: University of Texas.

Stangor, C., \& Ford, T. E. (1992). Accuracy and expectancy-confirming processing orientations and the development of stereotypes and prejudice. In W. Stroebe \& M. Hewstone (Eds.), European review of social psychology (Vol. 3, pp. 57-89). Chichester, England: Wiley.

Stangor, C., \& Schaller, M. (1996). Stereotypes as individual and collective representations. In N. Macrae, C. Stangor, \& M. Hewstone (Eds.), Stereotypes and stereotyping (pp. 3-37). New York: Guilford Press.

Tajfel, H., \& Turner, J. (1979). An integrative theory of intergroup conflict. In W. G. Austin \& S. Worchel (Eds.), The social psychology of intergroup relations (pp. 33-47). Monterey, CA: Brooks/Cole.

von Hippel, W., Sekaquaptewa, D., \& Vargas, P. (1997). The linguistic intergroup bias as an implicit indicator of prejudice. Journal of Experimental Social Psychology, 33, 490-509.

Watson, D., Clark, L. A., \& Tellegen, A. (1988). Development and validation of brief measures of positive and negative affect: The PANAS scales. Journal of Personality and Social Psychology, 54, 1063-1070.

Wicklund, R. A. (1997). Terror management accounts of other theories: Questions for the cultural worldview concept. Psychological Inquiry, 8, $54-58$.

Wills, T. A. (1981). Downward comparison principles in social psychology. Psychological Bulletin, 90, 245-271.

Wong, P. T., \& Weiner, B. (1981). When people ask "why" questions, and the heuristics of attributional search. Journal of Personality and Social Psychology, 40, 650-663.

Received June 13, 1997

Revision received April 29, 1999

Accepted April 29, 1999 